\title{
Review \\ A Brief Overview of Electrochromic Materials and Related Devices: A Nanostructured Materials Perspective
}

\author{
Aleksei Viktorovich Shchegolkov ${ }^{1, *}$, Sung-Hwan Jang ${ }^{2, *}$ (D), Alexandr Viktorovich Shchegolkov ${ }^{3}$, \\ Yuri Viktorovich Rodionov ${ }^{4}$, Anna Olegovna Sukhova ${ }^{5}$ and Mikhail Semenovich Lipkin ${ }^{1}$ \\ 1 Department of Chemical Technologies, Platov South-Russian State Polytechnic University (NPI), \\ 346428 Novocherkassk, Russia; lipkin@yandex.ru \\ 2 Department of Civil and Environmental Engineering, Hanyang University ERICA, Ansan 15588, Korea \\ 3 Department of Technology and Methods of Nanoproducts Manufacturing, Tambov State Technical University, \\ 392000 Tambov, Russia; Energynano@yandex.ru \\ 4 Department of Mechanics and Engineering Graphics, Tambov State Technical University, \\ 392000 Tambov, Russia; rodionow.u.w@rambler.ru \\ 5 Department of Nature Management and Environment Protection, Tambov State Technical University, \\ 392000 Tambov, Russia; apil1@yandex.ru \\ * Correspondence: alexxx5000@mail.ru (A.V.S.); sj2527@hanyang.ac.kr (S.-H.J.)
}

Citation: Shchegolkov, A.V.; Jang, S.-H.; Shchegolkov, A.V.; Rodionov, Y.V.; Sukhova, A.O.; Lipkin, M.S. A Brief Overview of Electrochromic Materials and Related Devices: A Nanostructured Materials Perspective. Nanomaterials 2021, 11, 2376. https:/ / doi.org/10.3390/nano11092376

Academic Editor: Yi Long

Received: 26 July 2021

Accepted: 3 September 2021

Published: 13 September 2021

Publisher's Note: MDPI stays neutral with regard to jurisdictional claims in published maps and institutional affiliations.

Copyright: (c) 2021 by the authors. Licensee MDPI, Basel, Switzerland. This article is an open access article distributed under the terms and conditions of the Creative Commons Attribution (CC BY) license (https:// creativecommons.org/licenses/by/ $4.0 /)$.

\begin{abstract}
Exactly 50 years ago, the first article on electrochromism was published. Today electrochromic materials are highly popular in various devices. Interest in nanostructured electrochromic and nanocomposite organic/inorganic nanostructured electrochromic materials has increased in the last decade. These materials can enhance the electrochemical and electrochromic properties of devices related to them. This article describes electrochromic materials, proposes their classification and systematization for organic inorganic and nanostructured electrochromic materials, identifies their advantages and shortcomings, analyzes current tendencies in the development of nanomaterials used in electrochromic coatings (films) and their practical use in various optical devices for protection from light radiation, in particular, their use as light filters and light modulators for optoelectronic devices, as well as methods for their preparation. The modern technologies of "Smart Windows", which are based on chromogenic materials and liquid crystals, are analyzed, and their advantages and disadvantages are also given. Various types of chromogenic materials are presented, examples of which include photochromic, thermochromic and gasochromic materials, as well as the main physical effects affecting changes in their optical properties. Additionally, this study describes electrochromic technologies based on $\mathrm{WO}_{3}$ films prepared by different methods, such as electrochemical deposition, magnetron sputtering, spray pyrolysis, sol-gel, etc. An example of an electrochromic "Smart Window" based on $\mathrm{WO}_{3}$ is shown in the article. A modern analysis of electrochromic devices based on nanostructured materials used in various applications is presented. The paper discusses the causes of internal and external size effects in the process of modifying $\mathrm{WO}_{3}$ electrochromic films using nanomaterials, in particular, GO/rGO nanomaterials.
\end{abstract}

Keywords: electrochromic materials; nanostructured electrochromic materials; electrochromism; color; "Smart Windows"; transition metal oxides (TMO); nanomaterials; graphene oxide (GO); reduced graphene oxide (rGO)

\section{Introduction}

Modern technology has a number of negative effects, such as atmospheric pollution, global warming, the reduction of fossil resources, etc. Therefore, one of the most important tasks in the world is to improve energy efficiency and energy savings. To this end, it is necessary to create new materials in a variety of sectors, including engineering, agroindustry, building construction, electronics manufacturing, etc., primarily with the aim of using new technologies and "smart" materials. 
Functional materials are dependent on their initial state and properties, as well as on the energy and external effects applied to the material. "Smart" materials have more than one functional state, depending on the impacting impulse, which can change over time [1].

Electrochromic materials (EC) are materials that are able to change color under the influence of an electric field. EC are of great interest, both from the scientific point of view and with respect to their application in various technical systems, including as the basis for the creation of electrochromic devices (ECD) with low power requirements, such as [2-4]:

- "Smart Windows";

- Displays;

- $\quad$ Reflective blinds;

- Variable reflection mirrors;

- Sensors.

The main purpose of ECD is protection against light in the visible wavelength range (380-780 nm). ECD include an electrochromic coating in the form of the EC film and a counter electrode placed in an electrolyte (ionic conductor), which is located between transparent conductive electrodes- $\mathrm{ITO}\left(\mathrm{In}_{2} \mathrm{O}_{3}-\mathrm{SnO}_{2}\right)$ or FTO $\left(\mathrm{SnO}_{2}-\mathrm{SnF}\right)$. The principle of ECD operation is the transformation of optical light flux and the modulation of the coefficient of light reflection/transmission, resulting in an electrochemical reaction, i.e., the "Smart Window" effect.

Thus, "Smart Window" technology allows savings due to use of smaller amounts of energy for air conditioning in summer, as well as for heating in winter; an average of more than $30 \%$ compared to conventional windows.

The purpose of this review is to systematize and summarize the data on organic, inorganic and nanostructured electrochromic materials and related devices over the past 50 years.

\section{2. “Smart Windows"}

There are chromogenic materials [3], better known as "smart" materials, that are currently experiencing great popularity. These materials modulate reflected or diffused light by means of physical effects of different types. The "Smart Window" based on chromogenic materials is widely used in architecture, cars (rear-view mirrors and intelligent window tinting), and aircraft illuminators (Boeing 787 Dreamliner) [3-5], while translucent structure technology [6] must also be mentioned. Chromogenic materials change color and transparency. The following types of chromogenic materials can be distinguished: electrochromic materials (EC) (external conditions_electric field); photochromic materials $(\mathrm{PhC})$ (external conditions-light); thermochromic materials (ThC) (external conditionsheat); gasochromic materials (GhC) (external conditions-gas); polymer-dispersed liquid crystals (PDLC) and liquid crystal dispersions (LCD); SPD—suspended particles device are placed between the two electroconductive coatings. These materials can serve as a basis for "Smart Window" technologies [7-11], which are shown in Figure 1.

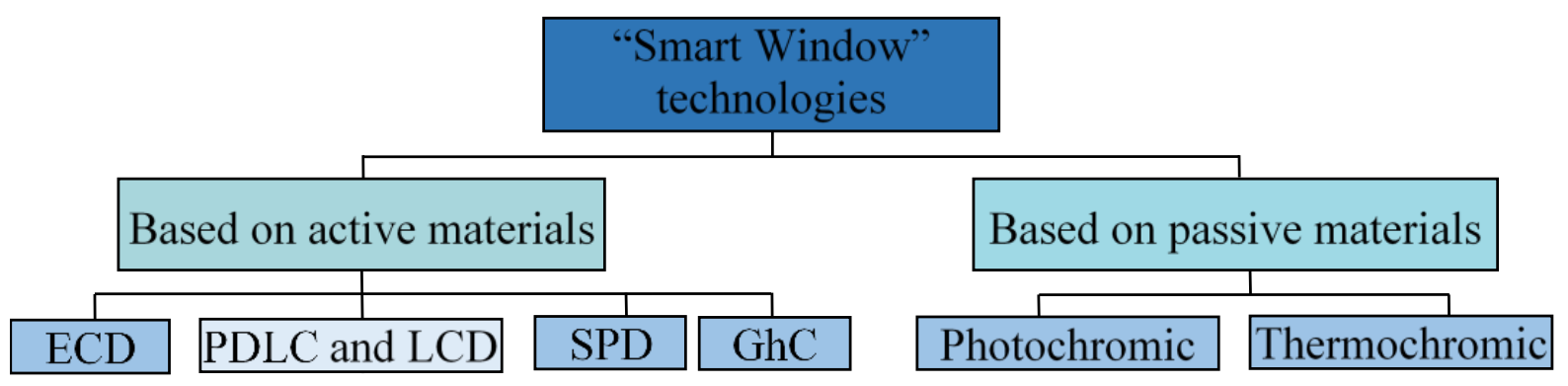

Figure 1. "Smart Windows" classification. 
The structures of SPD and PDLC windows [6,10-12] are shown in Figure 2. SPD technology (Figure 2a) uses suspended particles to modulate light transmission, arranging themselves in an alternating current field, and the film becomes transparent. In the absence of the electric field, the SPD window acquires color and absorbs light. The SPD window is similar in structure to the PDLC window (Figure 2b), apart from the fact that in the absence of an electric field, the film becomes semi-transparent.
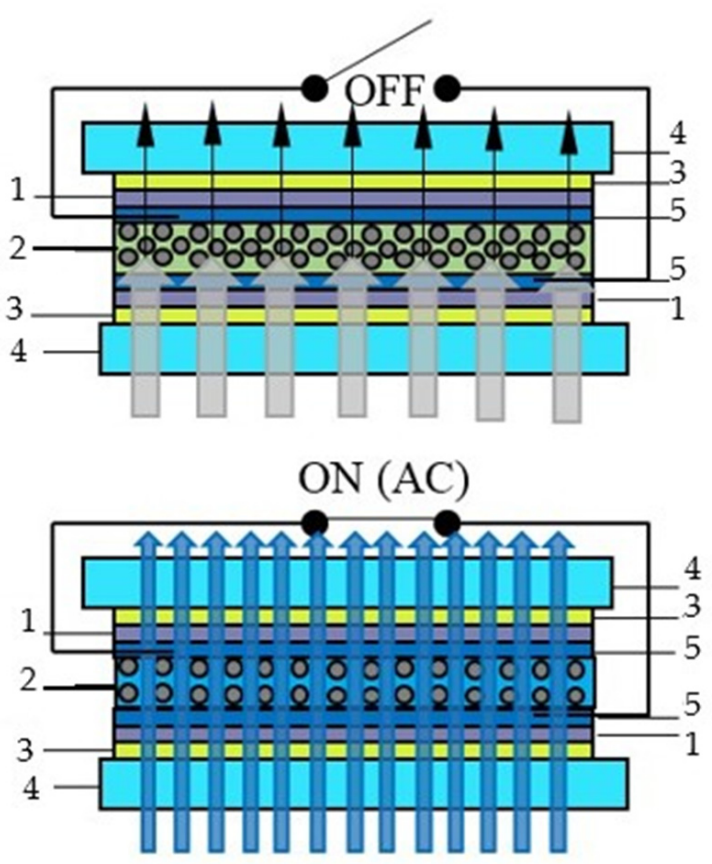

(a)
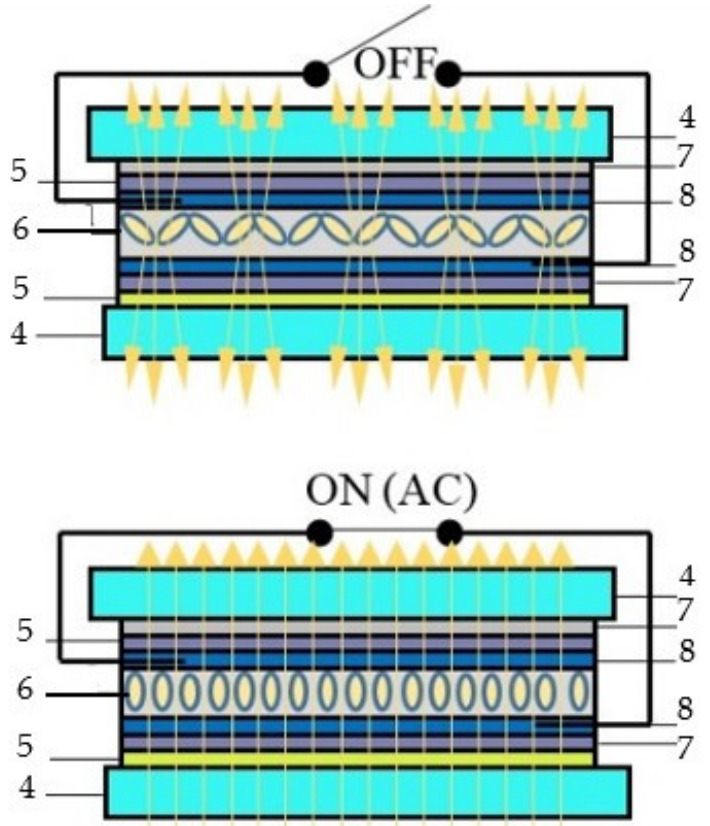

(b)

Figure 2. "Smart Windows" SPD and PDLC technology sandwich structures and operating principles: (a) SPD: off-light modulation mode, on—transparent mode; (b) PDLC: off-semi-transparent mode, on—transparent mode; 1—retaining film; 2-suspended particle; 3-adhesive layer; 4-glass; 5-conductor; 6-liquid crystal layer; 7-interlayer film; 8-liquid crystal.

Electrochromic windows (ECW) control the transmission of light in the visible spectrum and switches between tinted and transparent/semi-transparent states in response to low voltage signal (Figure 3). ECW create a comfortable indoor environment; moreover, they have lower power consumption in comparison with other chromogenic devices [13]: the ECW modulates reflected light under the control voltage, and in the absence of the control voltage, modulation of the transmitted light occurs [2-4,7].

The advantages of electrochromic technologies are as follows [14]:

- $\quad$ electric energy is required only during mode switching;

- $\quad$ low activation voltage (1-5 V);

- $\quad$ a wide variety of "Smart Window" tints (blue, grey, brown, etc.);

- $\quad$ in the bleached state, electrochromic devices have a transparency level of 50-70\%, in the colored state-10-25\%.

Table 1 shows the basic advantages and shortcomings of chromogenic materials used in "Smart Windows". 


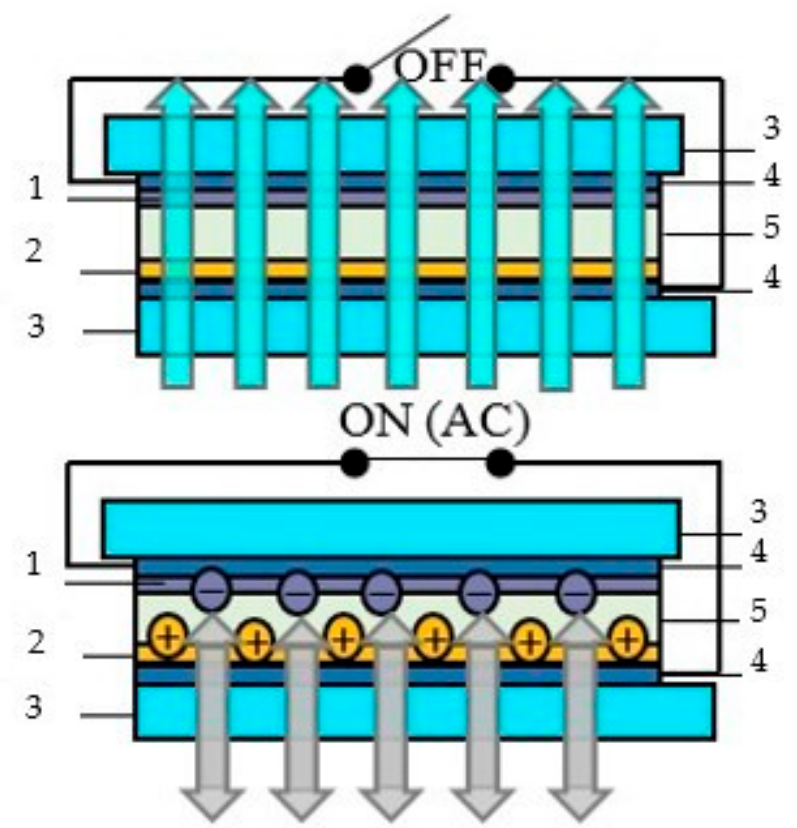

(a)

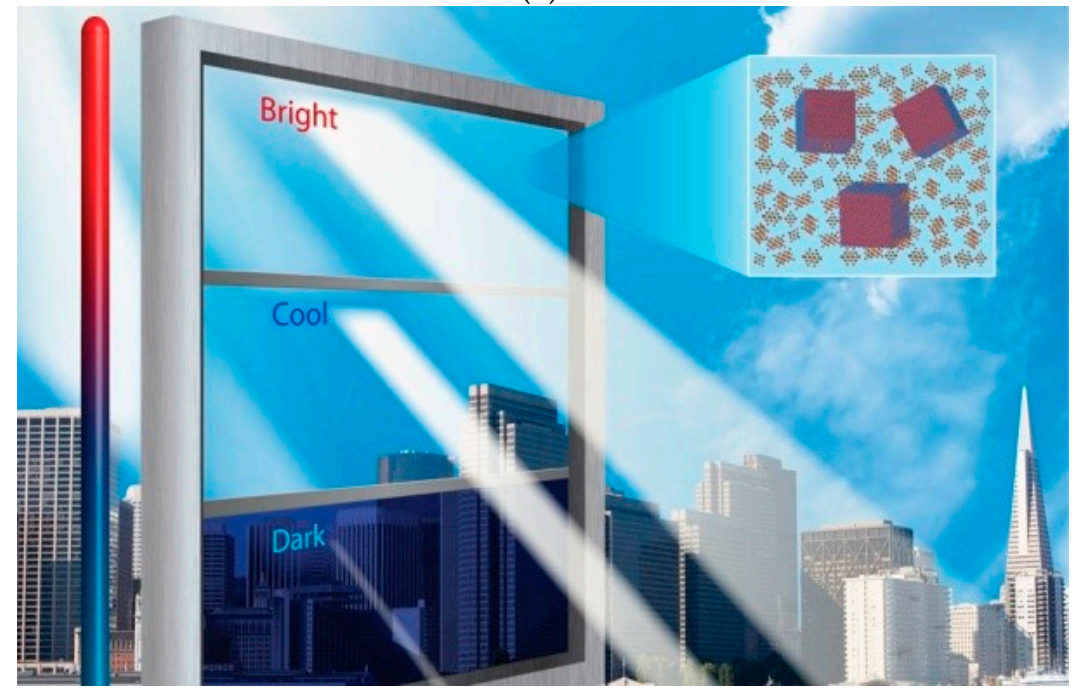

(b)

Figure 3. "Smart Window" electrochromic technology: (a) sandwich structure and operating principle (bleached state): transmitted and reflected light modulation: 1-electrochromic layer; 2 -ion storage layer; 3-glass; 4-conductive layer; 5-ion conductor/electrolyte; (b) total view.

Table 1. Comparison of "Smart Window" technologies.

\begin{tabular}{cccccc}
\hline Technology & $\begin{array}{c}\text { Energy } \\
\text { Efficiency, } \\
\text { W/m } \mathbf{m}^{2}\end{array}$ & $\begin{array}{c}\text { Energy Saving, } \\
\text { W/m } \mathbf{m}^{2} \text { (Energy } \\
\text { Saving in } \\
\text { Building) }\end{array}$ & $\begin{array}{c}\text { Transparency, } \\
\%\end{array}$ & $\begin{array}{c}\text { Modulation } \\
\text { Time, } \mathbf{s}\end{array}$ & $\begin{array}{c}\text { Cost, } \\
\text { (c.u. } / \mathbf{m}^{2} \text { ) }\end{array}$ \\
\hline ECW & + & + & + & - & - \\
\hline SPD & - & - & + & + & + \\
\hline PDLC & - & - & + & + & + \\
\hline LCD & - & - & + & + \\
\hline
\end{tabular}


Electronic devices emit high levels of electromagnetic radiation (EMR) in a wide frequency range, leading to electromagnetic pollution, which negatively influences biological objects and causing electronic device dysfunction [15]. Considering the fact that electromagnetic radiation basically penetrates through glass surfaces, the problem of creating a universal electrochromic film capable of absorbing or reflecting electromagnetic radiation is becoming relevant.

\section{Electrochromism and Electrochromic Materials: Classification and Applications}

Chromism (from ancient Greek $\chi \rho \tilde{\omega} \mu \alpha($ "color")) is a phenomenon of material color change under the influence of physical factors, such as electric field, heat, light or pressure [16].

At the end of the 1960s, scientist S. K. Deb discovered the phenomenon called electrochromism [17]. This newly discovered phenomenon belongs to the sphere of electrochemistry and physics [18]. S. K. Deb described a new electrophotographic system consisting of $\mathrm{WO}_{3}$ thin film and a thin-film photoconductive layer placed between two electrodes. When this composite structure was subjected to an electric field, an optical projection appeared. After subsequent modulation in the photoconductive layer, the oxide layer acquires the same color, and a visible image appears [17-19].

Since the middle of the 1970s, electrochromism has been considered to be a physical phenomenon associated with a reversible change in transparency or color under the influence of an electric field or electric current $[19,20]$. Electrochromism is traditionally defined as a reversible change in optical properties (transparency and/or reflectivity) during the oxidation-reduction reaction [21-23]. In some cases, there are more than two degrees of oxidation, and the material is capable of showing several colors depending on the current degree of oxidation (polyelectrochromic materials) [21]. Modern science uses a broad definition of electrochromism, including materials and devices used for the optical modulation of radiation in the visible and microwave ranges. Ref. [24] focuses on the problem of developing electrochromic displays that should replace LED and liquid crystal displays. In 1985, Svensson and Granqvist proposed using electrochromic materials in "Smart Windows" [14], and thus the term "Smart Window" appeared. The electrochromic reaction can be described by the electrochemical equation in oxidized form:

$$
\mathrm{O}+\mathrm{xe}^{-}+\text {Cation } \leftrightarrow \text { Reduced form, } \mathrm{R}
$$

Applications of electrochromism include:

- Control of energy transfer in different environments, for example, filtering solar radiation using "Smart Window" devices [25-27]. Fast mode switching (colored/bleached) is not required, but the device should be capable of filtering both visible and nearinfrared radiation. Moreover, the transparency of the window packages must be at least $70 \%$.

- Color displays [22,24], for example, advertising boards. The requirements are as follows: fast mode switching, color scheme varies only in the visible area. Moreover, color contrast should be high enough, transparent mode is not required.

- $\quad$ Mirror light modulators [7], for example, antiglare mirrors for cars. Fast mode switching and high transparency are not required.

\subsection{Classification of Electrochromic Materials}

There are several inorganic and organic EC that change their optical properties (transparency, color) during oxidation-reduction [28-32]. Switching between oxidation and reduction states leads to color formation, i.e., formation of new spectral peaks in the visible area. Inorganic EC include transition metal oxides (TMO) from groups IV-VI [32], and hexacyanometallates (Prussian blue). Organic EC include viologens, conjugated conductive polymers (polypyrrole, polythiophene, polyaniline and their derivatives, metal polymers, metal phthalocyanines) $[33,34]$. The viologen family $\left(4,4^{\prime}\right.$-dipyridinium compounds) has 
a general chemical formula as shown in Figure 4, where R may be an alkyl, cyclo-alkyl or other substitute, and X corresponds to halogen 4,4'-dipyridium compounds, because they turn a deep blue-purple on reduction [30]. The viologen ion as shown in Figure 4a can have a two-step reduction, i.e., a one-electron or a two-electron reduction. The general structure for viologens modifying the titania surface is shown in Figure 4c. Table 2 presents a list of the most popular EC.

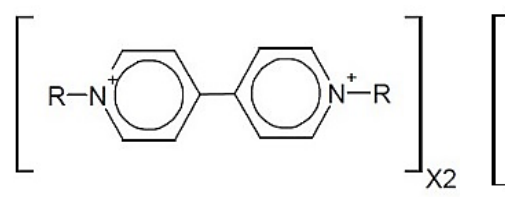

(a)<smiles>[R][n+]1ccc(-c2cc[n+]([2H])cc2)cc1</smiles>

(b)<smiles>[R][n+]1ccc(-c2cc[n+](OP(O)O)cc2)cc1</smiles>

(c)

Figure 4. Viologen: (a) general chemical formulae of viologen; (b) viologen ion; (c) general structure for viologens modifying the titania surface.

Table 2 shows a general classification of EC.

Table 2. General classification of EC.

\begin{tabular}{|c|c|c|c|}
\hline EC Class & Chemical Name & Application & Ref. \\
\hline \multicolumn{4}{|c|}{ Organic } \\
\hline $\begin{array}{l}\text { Conductive } \\
\text { polymers }\end{array}$ & $\begin{array}{l}\text { PEDOT (where EDOT }=\mathrm{C}_{6} \mathrm{H}_{6} \mathrm{O}_{2} \mathrm{~S} \text { ), } \\
\text { PPy }\left(\text { where } \mathrm{Py}=\text { Pyrrole }=\mathrm{C}_{4} \mathrm{H}_{5} \mathrm{~N}\right) \\
\left.\text { PT (where } \mathrm{T}=\text { thiophene }=\mathrm{C}_{4} \mathrm{H}_{4} \mathrm{~S}\right) \\
\text { PANI (where ANI = aniline }=\mathrm{C}_{6} \mathrm{H}_{4} \mathrm{~S} \text { ) }\end{array}$ & "Smart Windows", displays & {$[13,33]$} \\
\hline Viologens & $\begin{array}{c}\text { 3-aryl-4,5-bis (pyridine-4-yl) isoxazole } \\
\text { derivatives }\end{array}$ & $\begin{array}{l}\text { Antiglare mirrors and } \\
\text { displays }\end{array}$ & {$[21,28]$} \\
\hline $\begin{array}{l}\text { Transition metals and } \\
\text { lanthanoids }\end{array}$ & $\begin{array}{c}\text { poly }\left[\mathrm{Ru}^{\mathrm{II}}(\mathrm{vbpy})_{2}(\mathrm{py})_{2}\right] \mathrm{Cl}_{2}(\text { being py }= \\
\left.\text { pyridine }=\mathrm{C}_{5} \mathrm{H}_{5} \mathrm{~N}\right)\end{array}$ & Smart mirrors & {$[26,30]$} \\
\hline Metal phthalocyanines (Pc) & {$\left[\mathrm{Lu}(\mathrm{Pc})_{2}\right]$ being $\mathrm{Pc}=\mathrm{C}_{32} \mathrm{H}_{18} \mathrm{~N}_{8}$ et al. } & Displays & {$[7,30]$} \\
\hline \multicolumn{4}{|c|}{ Inorganic } \\
\hline $\begin{array}{l}\text { Transition metal oxides } \\
\text { (TMOs) }\end{array}$ & $\begin{array}{c}\mathrm{WO}_{3}, \mathrm{MoO}_{3}, \mathrm{~V}_{2} \mathrm{O}_{5}, \mathrm{TiO}_{2} \mathrm{Nb}_{2} \mathrm{O}_{5}, \mathrm{Ir}(\mathrm{OH})_{3} \\
\mathrm{NiO} \text { et al. }\end{array}$ & $\begin{array}{l}\text { "Smart Windows", antiglare } \\
\text { mirrors }\end{array}$ & {$[32,34]$} \\
\hline Prussian blue (PB) & $\begin{array}{c}\text { Prussian blue }\left(\mathrm{C}_{18} \mathrm{Fe}_{7} \mathrm{~N}_{18}\right) \text {, } \\
\text { Prussian brown }\left(\mathrm{C}_{6} \mathrm{Fe}_{2} \mathrm{~N}_{6}\right) \text {, Prussian } \\
\text { green }\left(\mathrm{C}_{3} \mathrm{FeN}_{3}\right), \text { Prussian white } \\
\left(\mathrm{C}_{6} \mathrm{Fe}_{3} \mathrm{~N}_{6}\right)\end{array}$ & "Smart Windows", displays & {$[7,29]$} \\
\hline
\end{tabular}

In general, organic EC, possessing color-changing abilities, exhibit faster response times and higher staining efficiencies than inorganic ones, but have a low UV protection index and show lower electrochemical stability. Therefore, mainly organic EC materials are used in electronic non-emissive displays [24,28]. Inorganic EC materials show high chemical stability and cyclicity, which makes them suitable for "Smart Windows" and large-scale data displays [35].

Electrochromic materials are classified according to their solubility and according to their redox states [29,30]. Classification of EC was introduced by I. F. Chang in 1975 [36]. According to this classification, there are three types of EC solubility in redox states [29]:

(1) Type I EC materials, such as viologen, heptyl, etc., are soluble in both their reduced and oxidized states.

(2) Type II EC materials are soluble in their colorless redox state but form a solid film on the electrode surface. 
(3) Type III EC materials are solids in both redox states, and they form an insoluble film on the electrode surface. Type III materials include groups IV, V transition metal oxides (TMO), conductive polymers, Prussian blue and metal polymers. Three types of mechanism for changing color/transparency (according to I. F. Chang) are presented in Figure 5.

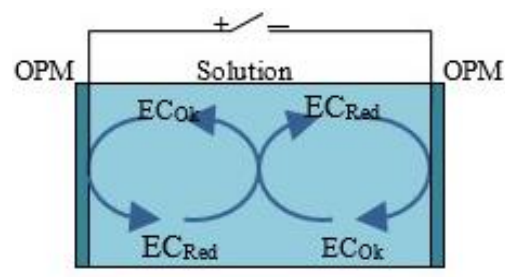

(a)

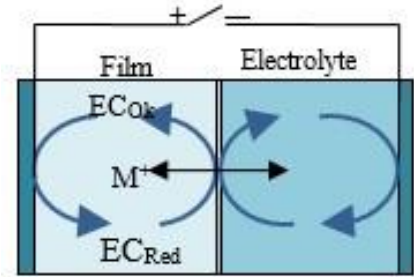

(b)

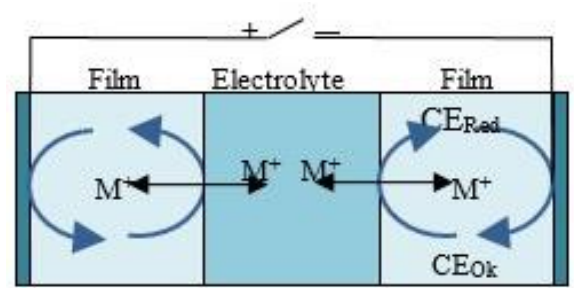

(c)

Figure 5. Types of ECW: (a) type I (solution); (b) type II (hybrid); (c) type III (battery-powered); EC-electrochromic layer; CE-counter-electrode layer; TCO-inorganic oxide.

The electrochromic reaction can be described by the following equation:

$$
\mathrm{EC}^{\mathrm{n}}+\mathrm{yCE}^{\mathrm{m}} \text { (bleached) } \leftrightarrow \mathrm{EC}^{\mathrm{n}-\mathrm{a}} \text { (coloured) }+\mathrm{yCE}^{(\mathrm{m}+\mathrm{a}) / \mathrm{y}}
$$

Table 3 contains examples of each type of EC.

Table 3. Classification of EC materials (according to I. F. Chang [36]).

\begin{tabular}{|c|c|c|c|c|c|}
\hline $\begin{array}{l}\text { EC } \\
\text { Type }\end{array}$ & & EC Material & $\begin{array}{c}\text { Electrochromic Reaction } \\
\text { Mechanism }\end{array}$ & Application & Ref. \\
\hline $\begin{array}{c}\mathrm{I} \\
\text { (solution) }\end{array}$ & $\begin{array}{l}(1) \\
\text { (2) }\end{array}$ & $\begin{array}{l}\text { Methylviologene (MV, } 1 \text {, } \\
\text { 10-dimethyl-4,4'-bipyrindnium, } \\
\text { 3-aryl-4,5-bis (pyridine-4-yl) } \\
\text { isoxazole; } \\
\text { Phenothiazine }\left(\mathrm{C}_{12} \mathrm{H}_{9} \mathrm{NS}\right) \text { in } \\
\text { non-aqueous solution }\end{array}$ & $\begin{array}{c}\mathrm{MV}^{2+}+ \\
\mathrm{e}^{-} \text {(bleached) } \leftrightarrow \mathrm{MV}^{+\bullet} \text { (colored) }\end{array}$ & $\begin{array}{l}\text { Night vision systems, } \\
\text { mirrors }\end{array}$ & {$[37,38]$} \\
\hline $\begin{array}{c}\text { II } \\
\text { (hybrid) }\end{array}$ & (1) & $\begin{array}{l}\text { Cyanophenylparaquate (CPQ, 1-1 } \\
\text { cyanophenyl- } 4,4^{\prime} \text {-bipyridine, } \\
\text { paraquat }=\mathrm{C}_{12} \mathrm{H}_{14} \mathrm{Cl}_{2} \mathrm{~N}_{2} \text {, otherwise } \\
\text { known as viologen, due to the } \\
\text { herbicide name) in aqueous solution } \\
\text { Heptyl or benzylviologene (HV or } \\
\text { BzV) or methoxyfluorene compounds } \\
\mathrm{C}_{3} \mathrm{H}_{4} \mathrm{Cl}_{2} \mathrm{~F}_{2} \mathrm{O} \text { in acetonitrile solution } \\
\left(\mathrm{C}_{2} \mathrm{H}_{3} \mathrm{~N}\right)\end{array}$ & $\begin{array}{c}\mathrm{CPQ}^{2+}+\mathrm{e}^{-}+ \\
\mathrm{X}^{-} \leftrightarrow\left[\mathrm{CPQ}^{+\bullet} \mathrm{X}^{-}\right]\end{array}$ & $\begin{array}{l}\text { Electrochromic paper, } \\
\text { "Smart Window" }\end{array}$ & [39-41] \\
\hline $\begin{array}{c}\text { III } \\
\text { (battery- } \\
\text { powered) }\end{array}$ & $\begin{array}{l}(2) \\
(3) \\
(4)\end{array}$ & $\begin{array}{l}\text { Almost all inorganic EC materials, } \\
\text { such as transition metal oxides: } \mathrm{WO}_{3} \text {, } \\
\mathrm{MoO}_{3}, \mathrm{~V}_{2} \mathrm{O}_{5}, \mathrm{TiO}_{2} \mathrm{Nb}_{2} \mathrm{O}_{5}, \mathrm{Ir}(\mathrm{OH})_{3} \text {, } \\
\mathrm{NiO} ; \\
\text { Phthalocyanine }\left(\mathrm{Pc}=\mathrm{C}_{32} \mathrm{H}_{18} \mathrm{~N}_{8}\right) \\
\text { Metal complexes and } \\
\text { hexacyanometallates, such as Prussian } \\
\text { blue }\left(\mathrm{PB}=\mathrm{C}_{18} \mathrm{Fe}_{7} \mathrm{~N}_{18}\right) \\
\text { Conductive polymers: polypyrrole } \\
\text { (PPy), polythiophene (PT), polyaniline } \\
\text { (PANI) }\end{array}$ & $\begin{array}{c}\mathrm{MO}_{\mathrm{y}}+\mathrm{x}\left(\mathrm{H}^{+}+\right. \\
\left.\mathrm{e}^{-}\right) \leftrightarrow \mathrm{H}_{\mathrm{x}} \mathrm{MO}_{\mathrm{y}(\text { colored })}\end{array}$ & $\begin{array}{l}\text { "Smart Window" } \\
\text { (Boeing 757), } \\
\text { Electro-chromic paper }\end{array}$ & {$[32,42,43]$} \\
\hline
\end{tabular}


Type I and Type II EC are self-erasing, since an electrical current is required to maintain the colored state, i.e., after the power is turned off, the ECW loses its color. Type III ECW (battery-powered) remain colored for some time after the voltage is removed. Electrochromic technologies make it possible to modulate the optical properties, such as color, light transmission coefficient $T(\lambda)$, reflection coefficient $R(\lambda)$, and absorption coefficient $A(\lambda)$, of materials according to Kirchhoff's law [44]:

$$
R(\lambda)+A(\lambda)+T(\lambda)=1
$$

All of these optical processes (Figure 6) are characterized by the EC transmittance $T(\lambda)$, absorption $A(\lambda)$ and reflectance $R(\lambda)$, which indicates the proportion of the incident light intensity that passes through, is absorbed by, or is reflected by the EC.

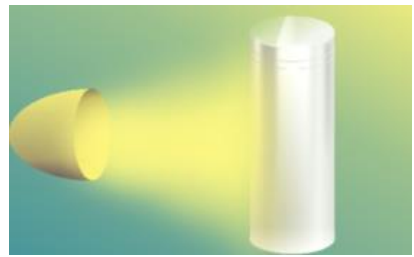

(a)

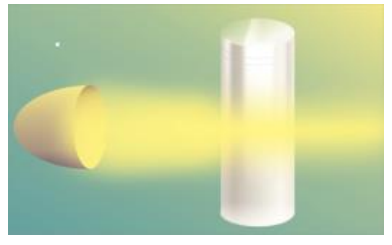

(b)

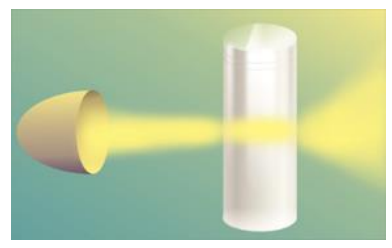

(c)

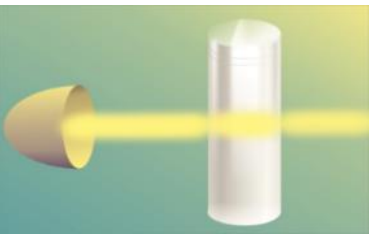

(d)

Figure 6. Interaction of radiation with an EC: (a) reflection; (b) absorption; (c) dispersion; (d) transmittance.

Electrochromic properties depend on the electrochromic film structure; thus, different EC have different absorption spectra, and, consequently, differ in color.

\subsection{Organic EC}

Organic films, such as conductive polymers, have multiple colored states, possess high optical contrast, and exhibit fast response time and high staining efficiency [45-49].

Electrochromic behavior is observed in conjugated pyridine derivatives such as viologens (Figure 7), which exhibit high cyclicity, low operating potential and other valuable properties $[50,51]$. Viologens exist in solid crystalline form and in powder form. The name 'viologen' alludes to violet, one color it can exhibit (Figure 7).

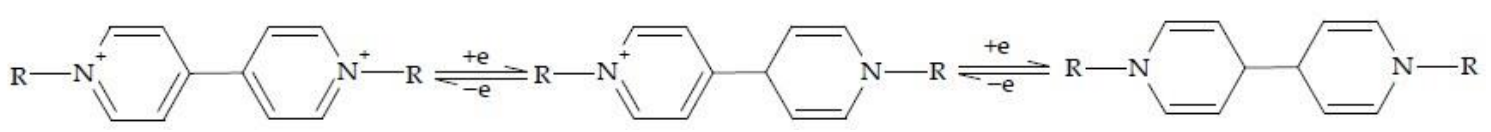

(a)

(b)

(c)

Figure 7. Three general viologen redox states (in terms of electron transfer): (a) dication; (b) radical cation; (c) neutral state.

Viologens are used in RGB (red, green, blue) devices (Figure 8), which reproduce three main colors, red, green and blue, although research in this area is not yet well developed. Modern technologies require the use of multicolor EC, which, in turn, necessitates the creation of new functional composites [50]. 


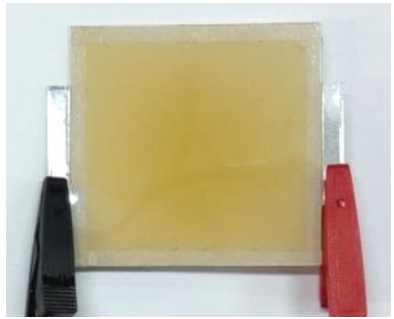

$\mathrm{E}=0 \mathrm{~V}$

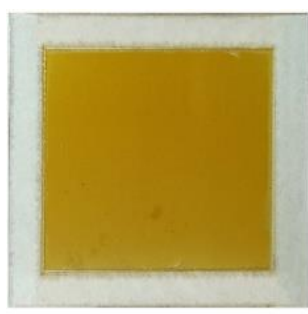

$\mathrm{E}=\mathbf{0} \mathrm{V}$
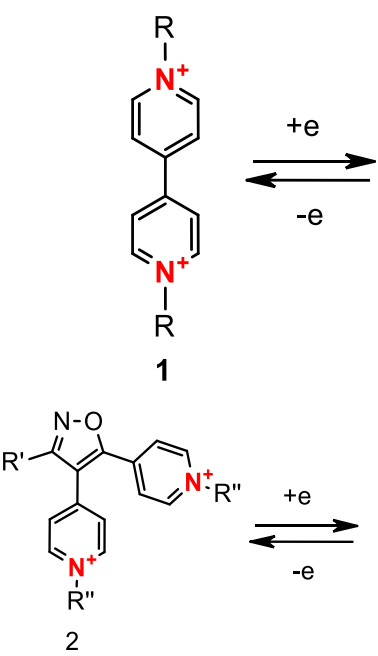

2

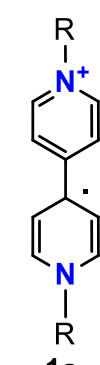

$1 a$

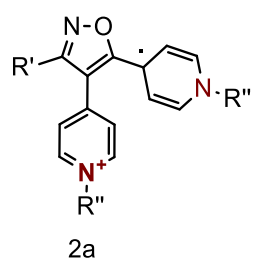

$2 a$

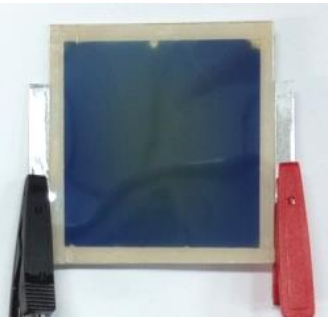

$\mathrm{E}=1.5 \mathrm{~V}$

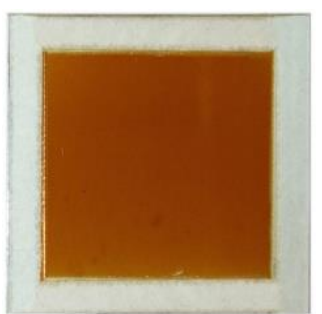

$\mathrm{E}=1.5 \mathrm{~V}$

Figure 8. Electrochromic transition cycle.

The advantages of organic EC include compatibility with flexible substrates, low production cost and the possibility of adjusting their synthetic material properties.

Phenylenediamine (PD) derivatives are of interest due to their stable electrochemical reactions at the anode [52]. It is interesting to note that neutral arylamine is often colorless (it mostly absorbs UV light), but in redox states, it exhibits vivid color (Figure 9). Phenylenediamines exhibit modulated visible absorption properties and high redox stability, which makes them suitable for RGB devices [53].

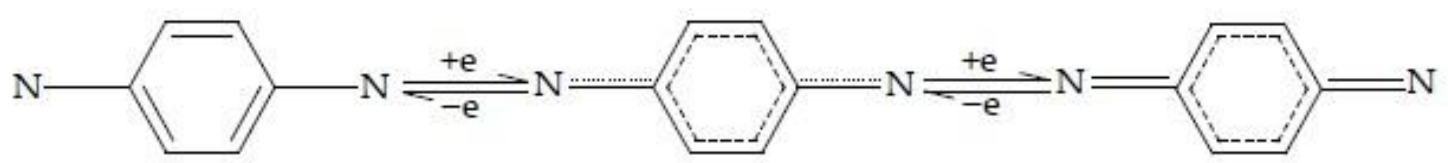

Neutral:

Non-colored

Absorbs UV radiation
Radical cation:

Colored

High absorption in the near-infrared range
Dication:

Colored

Weak absorption in the near-infrared range

Figure 9. Redox chemistry of Phenylenediamine (Wurster's blue), description of optical behavior in redox states.

The color-changing abilities of conductive PEDOT polymers [54] are useful in electrochromic non-emissive displays (Figure 10).

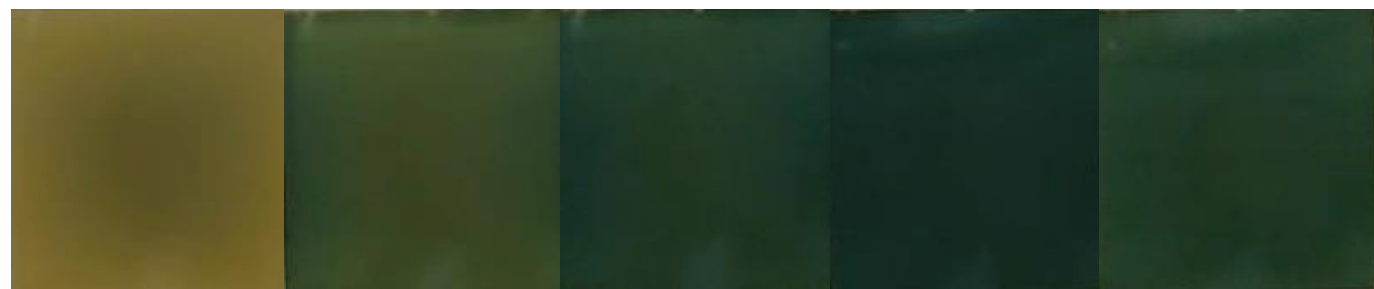

(a)

(b)

(c)

(d)

(e)

Figure 10. New electrochromic compounds obtained by reactions involving the cycloaddition of nitrile oxides to 1,2-bis (4-pyridinyl) ethylene derivatives (electrochromic transition): (a)—neutral state; (b-e)—oxidized states. 
Heterocyclic aromatic compounds (Figure 11), such as thiophene, aniline, furan, carbazole, azulene and indole $[55,56]$, can be oxidized chemically or electrochemically to form anion-doped polypyrrole (PPy), polythiophene (PT) or polyaniline (PANI), poly(3methylaniline) (MEPA), poly(3-methyl-thiophene) (P3MTh), and poly(3-methylpyrrole) (P3MPy). A change in the redox state (oxidized conductive state, reduced non-conductive state, neutral state) leads to changes in color caused by significant changes in the visible and near-infrared absorption spectra that vary depending on the degree of oxidation/reduction Switching between polymer films in their colored (reduced) and uncolored (oxidized) states changes their color from yellow to orange, red, purpuric, dark blue, green, light blue, and black [57].<smiles>c1cc[nH]c1</smiles><smiles>c1ccsc1</smiles><smiles>Nc1ccccc1</smiles><smiles>c1ccoc1</smiles><smiles>c1ccc2c(c1)[nH]c1ccccc12</smiles>

\section{Carbazole}<smiles>c1ccc2cccc-2cc1</smiles>

Azolene<smiles>C1=CC2C=CNC2C=C1</smiles>

Indole

Figure 11. Molecules of heterocyclic aromatic compounds.

Table 4 shows conductive polymers obtained by the oxidation of monomeric aromatic compounds (neutral and oxidized states).

Table 4. Conductive polymers obtained by the oxidation of monomeric aromatic compounds (neutral and oxidized states).

\begin{tabular}{|c|c|c|c|c|c|c|}
\hline \multirow[b]{2}{*}{ State } & \multicolumn{6}{|c|}{ Organic EC } \\
\hline & PANI & P3MPy & MEPA & P3MT & PPY & PT \\
\hline Neutral & 4 & 27 & & & & \\
\hline Oxidized & & & & & & \\
\hline
\end{tabular}

The shortcomings of polymer films include their low electrochemical stability and, consequently, their low oxidation number [28-30]. The addition of inorganic materials improves the properties of electrochromic conductive polymers [58]. Inorganic materials improve the staining efficiency and reduce the switching time, but do not affect the electrochemical properties of the polymer; therefore, the problem of improving polymer electrochemical stability is still relevant. Electrochromic films, such as $\mathrm{WO}_{3}, \mathrm{Nb}_{2} \mathrm{O}_{5}, \mathrm{NiO}$, are preferable due to their high stability and durability.

\subsection{Transition Metal Oxides}

Inorganic materials include a large group of EC, mostly the $\mathrm{TMO} \mathrm{Me}_{\mathrm{x}} \mathrm{O}_{\mathrm{y}}$ (Figure 12). The most common TMO [32,59], such as molybdenum (VI) oxide, vanadium (V) oxide, niobium (V) oxide, iridium (III) oxide, tungsten (VI) oxide, are in the form of an octahedron $\mathrm{MeO}_{6}$ (Figure 13). The crystal structure of $\mathrm{CWO}_{3}$ perovskite shown in Figure 14. 


\begin{tabular}{|c|c|c|c|c|c|c|c|c|c|c|}
\hline \multirow{2}{*}{$\begin{array}{c}\text { Group } \rightarrow \\
\text { Period } \downarrow\end{array}$} & \multicolumn{5}{|c|}{ Cathodic coloration } & \multicolumn{5}{|c|}{ Anodic coloration } \\
\hline & III & IV & $\mathbf{V}$ & VI & VII & \multicolumn{3}{|c|}{ VIII } & $\mathbf{I}$ & II \\
\hline 4 & $\begin{array}{l}21 \\
\mathrm{Sc}\end{array}$ & $\begin{array}{l}22 \\
\mathrm{Ti}\end{array}$ & $\begin{array}{c}23 \\
\mathbf{V}\end{array}$ & $\begin{array}{l}24 \\
\mathrm{Cr}\end{array}$ & $\begin{array}{c}25 \\
\text { Mn }\end{array}$ & $\begin{array}{l}26 \\
\mathrm{Fe}\end{array}$ & $\begin{array}{l}27 \\
\text { Co }\end{array}$ & $\begin{array}{l}28 \\
\mathrm{Ni}\end{array}$ & $\begin{array}{c}29 \\
\mathrm{Cu}\end{array}$ & $\begin{array}{l}30 \\
\mathrm{Zn}\end{array}$ \\
\hline 5 & $\begin{array}{l}39 \\
Y\end{array}$ & $\begin{array}{l}40 \\
\mathrm{Zr}\end{array}$ & $\begin{array}{l}41 \\
\mathrm{Nb}\end{array}$ & $\begin{array}{c}42 \\
\text { Мo }\end{array}$ & $\begin{array}{c}43 \\
\text { Tc }\end{array}$ & $\begin{array}{c}44 \\
\text { Ru }\end{array}$ & $\begin{array}{r}45 \\
\text { Rh }\end{array}$ & $\begin{array}{l}46 \\
\text { Pd }\end{array}$ & $\begin{array}{c}47 \\
\mathbf{A g}\end{array}$ & $\begin{array}{c}48 \\
\mathrm{Cd}\end{array}$ \\
\hline 6 & $*$ & $\begin{array}{c}72 \\
\text { Hf }\end{array}$ & $\begin{array}{r}73 \\
\text { Ta }\end{array}$ & $\begin{array}{l}74 \\
\text { W }\end{array}$ & $\begin{array}{l}75 \\
\operatorname{Re}\end{array}$ & $\begin{array}{l}76 \\
\text { Os }\end{array}$ & $\begin{array}{l}77 \\
\text { Ir }\end{array}$ & $\begin{array}{l}78 \\
\text { Pt }\end{array}$ & $\begin{array}{r}79 \\
\mathrm{Au}\end{array}$ & $\begin{array}{c}80 \\
\mathrm{Hg}\end{array}$ \\
\hline
\end{tabular}

Figure 12. Electrochromic transition metal oxides. *-lantanoids.

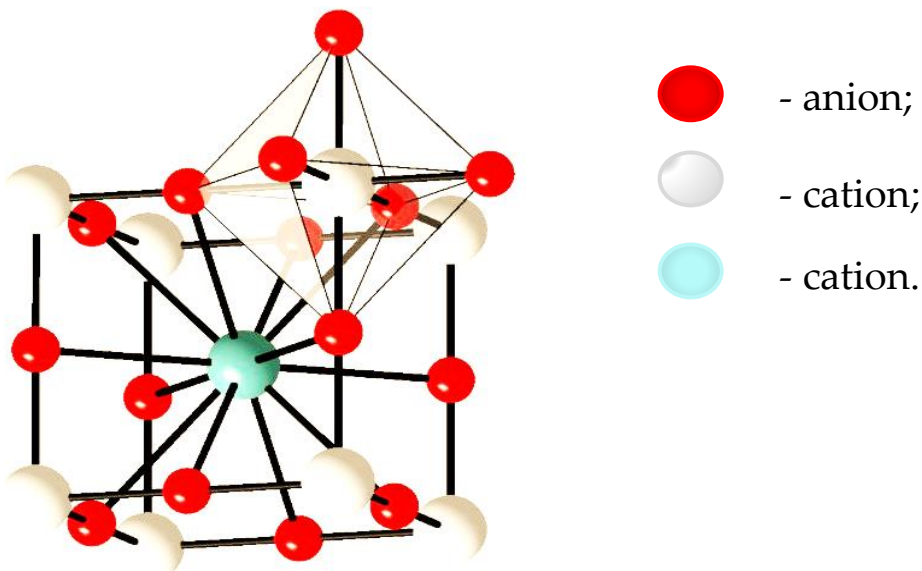

Figure 13. Crystal structure of $\mathrm{MeO}_{6}$ perovskite.

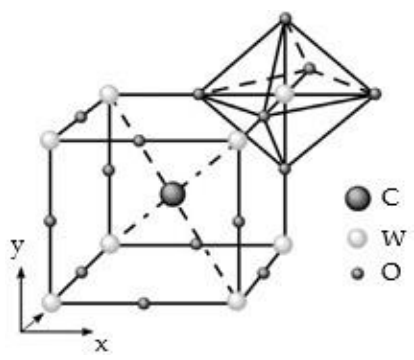

(a)

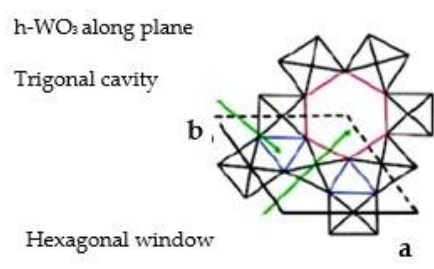

(b)

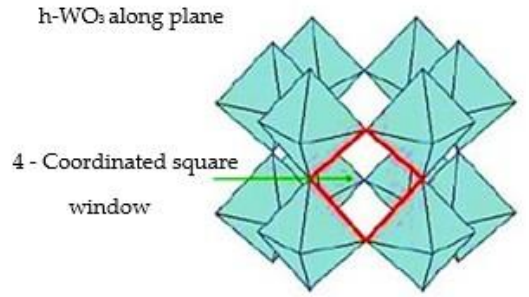

(c)

Figure 14. Crystal structure of $\mathrm{CWO}_{3}$ perovskite: (a) general view; (b) h-WO 3 along plane; (c) h-WO 3 along plane.

In the mentioned structures, electrochromic effects occur due to electron-ion separation. As a result, metal atoms are introduced into TMO, and the valence electrons move to the d-levels of the transition metal ion, reducing it. Evidently, the injected ions should possess a high diffusion coefficient and a high solubility in the lattice of TMO [18,20].

There are several highly efficient $\mathrm{TMO}\left(\mathrm{IrO}_{2}\right.$ [60], $\mathrm{MoO}_{3}$ [61], $\mathrm{NiO}$ [62], $\mathrm{TiO}_{2}$ [63], $\left.\mathrm{WO}_{3}[42,59]\right)$ that are colorless in the oxidized state and colored in the reduced state (cathodic EC, color change is induced by ion injection). Inorganic compounds that are colorless in their reduced state and colored in their oxidized state are called anodic EC (color change is induced by ion extraction). 
Vanadium oxides [64] exhibit hybrid features, and ECD usually contain two EC films [32,59]; therefore, it would be relevant to simultaneously use a cathodic oxide (for example, Mo or $\mathrm{Nb}$ ) and an anodic oxide (for example, Ni or Ir) [61,63].

EC exhibit polychromism [65], for example, amorphous $\mathrm{Nb}_{2} \mathrm{O}_{5}$ is brown in its colored state, while crystalline $\mathrm{Nb}_{2} \mathrm{O}_{5}$ acquires a blue color; $\mathrm{WO}_{3}$ is blue in its colored state, while $\mathrm{TiO}_{2}$ obtains its color (blue or grey) as a result of ion injection $\left(\mathrm{H}^{+}\right.$or $\mathrm{Li}^{+}$, respectively). The most investigated cathodic $\mathrm{EC}$ is $\mathrm{WO}_{3}$ [66]. The color change mechanism has still not been sufficiently investigated, but most scientists agree that the extraction and injection of electrons and metal cations $\left(\mathrm{Li}^{+}, \mathrm{H}^{+}, \mathrm{Na}^{+}, \mathrm{K}^{+}\right.$, etc.) play a crucial role in color change. $\mathrm{NiO}$ and $\mathrm{IrO}_{2}$ are the most popular anodic EC. High concentrations of cations in the electrolyte, which is an ion conductor, significantly affect the electrochromic properties of the TMO, such as switching time, cyclicity and staining efficiency.

The majority of TMO have a band gap of $1-5 \mathrm{eV}$ (Figure 15), and therefore occupy an intermediate position between semiconductors and dielectrics [67]. EC behavior is dependent on TMO structure. It should be noted that structural and impurity defects directly affect the properties-particularly the physicochemical properties—of the EC under study.

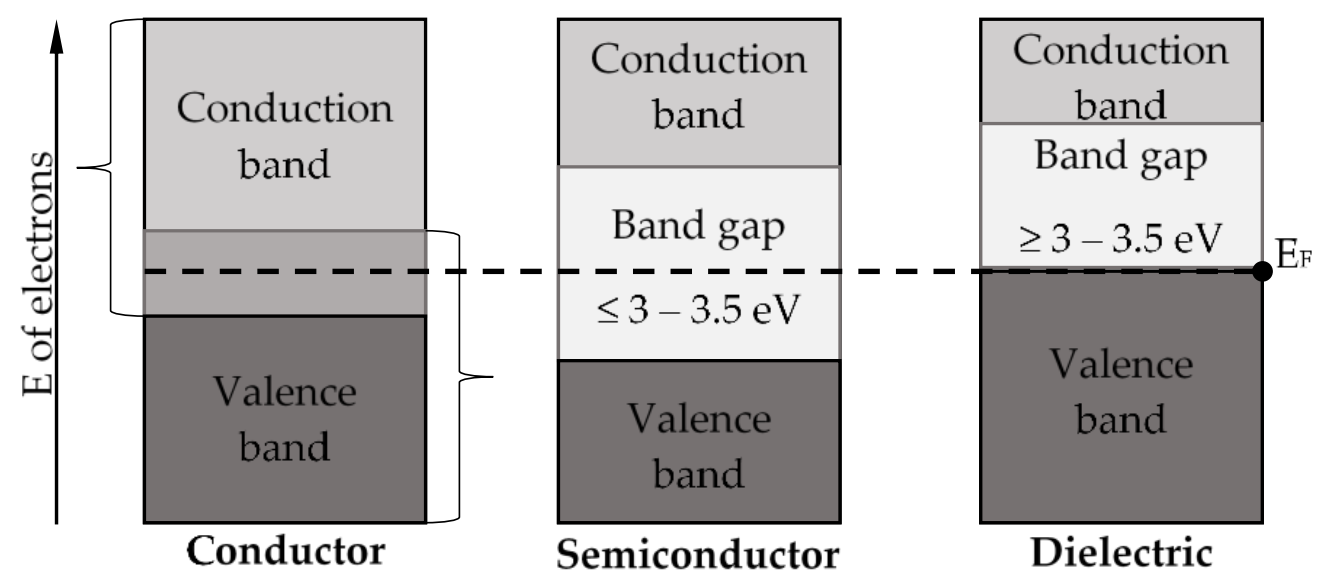

Figure 15. Classification of materials by conductivity (according to zone theory).

The optical band gap can be calculated according to Equation (4) [37]:

$$
\alpha \mathrm{hv}=\mathrm{A}\left(\mathrm{hv}-\mathrm{E}_{\mathrm{g}}\right)^{\mathrm{n}}
$$

where $\alpha$ is the absorption coefficient, which can be measured by the ultraviolet spectrophotometer; $\mathrm{h}$ is the Planck constant; $\mathrm{v}$ is the light frequency; A is a proportionality constant; $\mathrm{E}_{\mathrm{g}}$ is the optical band gap; $\mathrm{n}$ is a number that is $\frac{1}{2}$ for the direct band gap semiconductor and 2 for the indirect band gap semiconductor.

The $\mathrm{E}_{\mathrm{g}}$ of the $\mathrm{WO}_{3}$ films decreased from $3.62 \mathrm{eV}$ to $3.30 \mathrm{eV}$ when the annealing temperature was increased. In addition, the $\mathrm{E}_{\mathrm{g}}$ of the colored $\mathrm{WO}_{3}$ films was less than that of the bleached $\mathrm{WO}_{3}$ films [38]. The different band gap demonstrates that the conductivity of the $\mathrm{WO}_{3}$ film is enhanced with decreasing $\mathrm{E}_{\mathrm{g}}$, while the high conductivity increased the electrochromic response time.

The transparency of inorganic EC with high staining efficiency varies in response to the low-voltage signal. $\mathrm{WO}_{3}$ and $\mathrm{NiO}$ (Table 5) have a staining efficiency of $\sim 40 \mathrm{sm}^{2} \cdot \mathrm{C}^{-1}$, while for organic EC films, such as PEDOT, this value is more than $100 \mathrm{sm}^{2} \cdot \mathrm{C}^{-1}[32,39]$. Actually, TMO have a high physical and chemical stability. 
Table 5. Color variation in $\mathrm{WO}_{3}, \mathrm{NiO}$ and $\mathrm{WO}_{3} / \mathrm{NiO}$ electrochromic films (colored and bleached states).

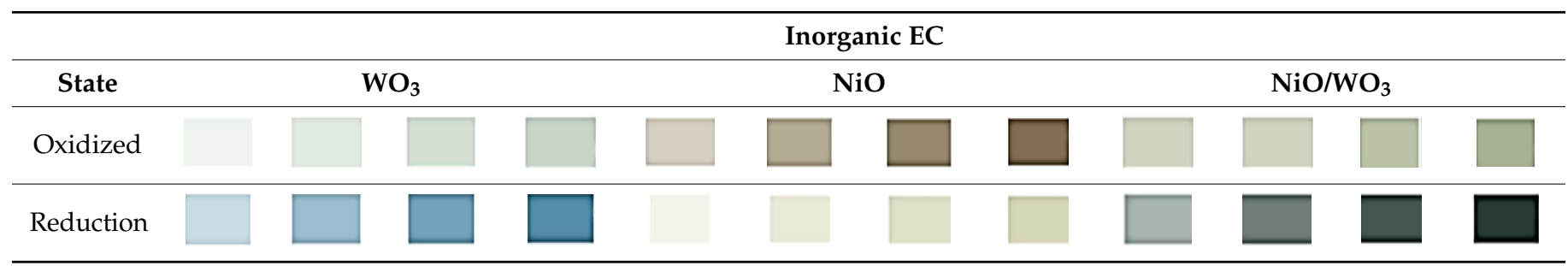

TMO belong to type III materials, according to I. F. Chang's classification. Both anodic (A) and cathodic (C) reactions are possible, depending on the redox state of the electrochromic film. Table 6 describes the electrochemical anodic and cathodic reactions of certain oxides.

Table 6. Electrochemical reactions of certain oxides.

\begin{tabular}{|c|c|c|c|}
\hline Metal Oxide & Electrochemical Reaction & Color Change & Reaction Type \\
\hline Manganese oxide (II) & $\mathrm{MnO}_{2}+\mathrm{ze}^{-}+\mathrm{zH}^{+} \Leftrightarrow \mathrm{MnO}_{(2-\mathrm{z})}(\mathrm{OH})$ & $\begin{array}{c}\text { Yellow } \leftrightarrow \\
\text { brown }\end{array}$ & $\mathrm{A}$ \\
\hline Cobalt oxide (II) & $3 \mathrm{CoO}+2 \mathrm{OH}^{-} \Leftrightarrow \mathrm{Co}_{3} \mathrm{O}_{4}+\mathrm{H}_{2} \mathrm{O}+2 \mathrm{e}^{-}$ & $\begin{array}{l}\text { Green } \leftrightarrow \\
\text { light blue }\end{array}$ & A \\
\hline Nickel oxide (II) & $\mathrm{NiO}_{\mathrm{x}} \mathrm{H}_{\mathrm{y}} \Leftrightarrow\left[\mathrm{Ni}^{\mathrm{II}}(1-\mathrm{z}) \mathrm{Ni}_{\mathrm{z}}{ }^{\mathrm{III}}\right] \mathrm{O}_{\mathrm{x}} \mathrm{H}_{(\mathrm{y}-\mathrm{z})}+\mathrm{zH}^{+}+\mathrm{ze}^{-}$ & $\begin{array}{l}\text { Colorless } \leftrightarrow \\
\text { brown }\end{array}$ & $\mathrm{A}$ \\
\hline Molybdenum oxide (VI) & $\mathrm{MoO}_{3}+\mathrm{x}\left(\mathrm{Li}^{+}+\mathrm{e}^{-}\right) \Leftrightarrow \mathrm{Li}_{\mathrm{x}} \mathrm{Mo}_{(1-\mathrm{x})}^{\mathrm{VI}} \mathrm{Mo}_{\mathrm{x}} \mathrm{O}_{3} \frac{1}{2}$ & Colorless $\leftrightarrow$ blue & C \\
\hline Vanadium oxide (V) & $\begin{array}{l}\mathrm{Li}_{\mathrm{x}} \mathrm{V}_{2} \mathrm{O}_{5} \Leftrightarrow \mathrm{V}_{2} \mathrm{O}_{5}+\mathrm{x}\left(\mathrm{Li}^{+}+\mathrm{e}^{-}\right)(\mathrm{A}) \\
\mathrm{V}_{2} \mathrm{O}_{5}+\mathrm{x}\left(\mathrm{M}^{+}+\mathrm{e}^{-}\right) \Leftrightarrow \mathrm{M}_{\mathrm{x}} \mathrm{V}_{2} \mathrm{O}_{5}(\mathrm{C})\end{array}$ & $\begin{aligned} \text { Blue } \leftrightarrow \text { brown }(\mathrm{A}) \\
\text { Yellow } \leftrightarrow \text { light blue }(\mathrm{C})\end{aligned}$ & $\mathrm{C} / \mathrm{A}$ \\
\hline Cerium oxide (IV) & $\mathrm{CeO}_{2}+\mathrm{x}\left(\mathrm{Li}^{+}+\mathrm{e}^{-}\right) \Leftrightarrow \mathrm{Li}_{\mathrm{x}} \mathrm{CeO}_{2}$ & Yellow $\leftrightarrow$ transparent & C \\
\hline Niobium oxide (V) & $\mathrm{Nb}_{2} \mathrm{O}_{5}+\mathrm{x}\left(\mathrm{Li}^{+}+\mathrm{e}^{-}\right) \Leftrightarrow \mathrm{Li}_{\mathrm{x}} \mathrm{Nb}_{2} \mathrm{O}_{5}$ & Colorless $\leftrightarrow$ light blue & C \\
\hline Ruthenium oxide (IV) & $\mathrm{RuO}_{2} \cdot 2 \mathrm{H}_{2} \mathrm{O}+\mathrm{H}_{2} \mathrm{O}+\mathrm{e}^{-} \Leftrightarrow 0,5\left(\mathrm{Ru}_{2} \mathrm{O}_{3} \cdot 5 \mathrm{H}_{2} \mathrm{O}\right)+\mathrm{OH}^{-}$ & Blue $\leftrightarrow$ brown/yellow & C \\
\hline Indium oxide (ITO) & $\mathrm{In}_{2} \mathrm{O}_{3}+2 \mathrm{x}\left(\mathrm{Li}^{+}+\mathrm{e}^{-}\right) \Leftrightarrow \mathrm{Li}_{2 \mathrm{x}} \mathrm{In}^{\mathrm{III}}{ }_{(1-\mathrm{x})} \mathrm{In}_{\mathrm{x}}^{\mathrm{I}} \mathrm{O}_{3}$ & Colorless $\leftrightarrow$ light blue & C \\
\hline Iridium oxide (III) & $\mathrm{Ir}(\mathrm{OH})_{3} \Leftrightarrow \mathrm{IrO}_{2} \cdot \mathrm{H}_{2} \mathrm{O}+\mathrm{H}^{+}+\mathrm{e}^{-}$ & Colorless $\leftrightarrow$ blue/grey & C \\
\hline Tungsten oxide (VI) & $\begin{array}{l}\mathrm{W}^{\mathrm{V}} \mathrm{O}_{3}+\mathrm{x}\left(\mathrm{Li}^{+}+\mathrm{e}^{-}\right) \Leftrightarrow \mathrm{Li}_{\mathrm{x}} \mathrm{W}_{(1-\mathrm{x})}^{\mathrm{VI}} \mathrm{W}_{\mathrm{x}}^{\mathrm{V}} \mathrm{O}_{3} \\
\mathrm{~W}^{\mathrm{V}} \mathrm{O}_{3}+\mathrm{x}\left(\mathrm{H}^{+}+\mathrm{e}^{-}\right) \Leftrightarrow \mathrm{H}_{\mathrm{x}} \mathrm{W}_{(1-\mathrm{x})}^{\mathrm{VI}} \mathrm{W}_{\mathrm{x}}^{\mathrm{V}} \mathrm{O}_{3}\end{array}$ & Colorless $\leftrightarrow$ blue/black & $\mathrm{C}$ \\
\hline
\end{tabular}

\section{4. $\mathrm{WO}_{3}$ Electrochromic Films}

Tungsten (VI) oxide $\left(\mathrm{WO}_{3}\right)$ is the most universal EC, and its electrochromic properties were first described by S. K. Deb in 1969 [17]. This oxide is still widely investigated [32,40]. High functionality, high staining efficiency, high contrast, high chemical stability, and long life cycle are all features that make tungsten (VI) oxide useful in practice [41,43]. $\mathrm{WO}_{3}$ electrochromic films exhibit a deep blue color, preserve their color for some hours after the voltage is removed (electrochromic memory), and demonstrate high cyclic stability in comparison to other TMO [32]. The electrochromic mechanism of $\mathrm{WO}_{3}$ film is shown in Figure 16. 


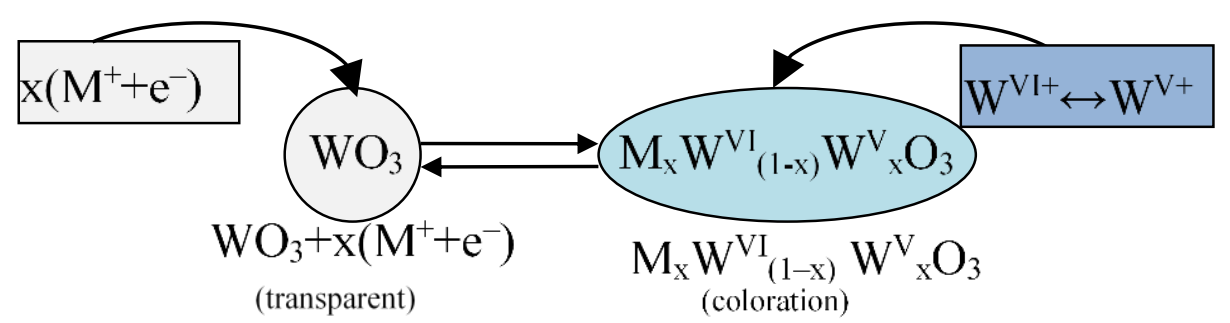

Figure 16. Electrochromic mechanism of $\mathrm{WO}_{3}$ film.

$\mathrm{WO}_{3}$ films have different colors depending on $\mathrm{x}$. At low values of $\mathrm{x}$, the film is colored blue, and at high values of $x$, it has either a red or golden tint. These phenomena are associated with the fact that, firstly, $\mathrm{WO}_{3}$ is partially reduced to the oxidation state $\mathrm{V}+$, and secondly, the addition of the $\mathrm{Li}^{+}$cation occurs; all this leads to changes in the band gap and, as a consequence, in the light transmittance of the TMO.

At the same time, the molecular reaction in $\mathrm{WO}_{3}$ films can be described as follows [68]:

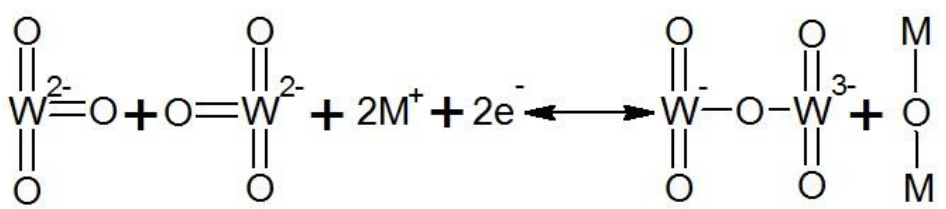

In [69], it was shown that the electrochemical reaction at the $\mathrm{WO}_{3}$ /electrolyte interface plays an imperative role in the electrochromic performance of $\mathrm{WO}_{3}$ electrodes, and the lithium-ion transformation mechanism at the $\mathrm{WO}_{3}$ /electrolyte interface was demonstrated, wherein the states are replaced from one phase to another.

The high efficiency of amorphous $\mathrm{WO}_{3}$ films $[40,70]$ manifests in a reversible switch from transparent to dark blue during electrochemical redox reactions (Figure 16). Electrochromic properties, such as staining efficiency, and switching time are dependent on the atomic structure, nanoparticle size, pore size and absorption properties [71,72]. O. F. Schirmer suggested that the optical absorption phenomenon in $\mathrm{WO}_{3}$ films was due to small polaron (SP, charged and polarized quasiparticles) transitions from $\mathrm{W}^{(\mathrm{V})}$ ions to $\mathrm{W}^{(\mathrm{VI})}$ ones. In $[42,69,73]$, the light absorption mechanism in amorphous $\mathrm{WO}_{3}$ was is described as the interval optically induced transfer of $5 \mathrm{~d} 1$-electron of the $\mathrm{W}^{(\mathrm{V})}$ ion $(\mathrm{A})$ to the adjacent empty $5 \mathrm{~d} 0$-orbital of the $\mathrm{W}^{(\mathrm{VI})}$ ion (B):

$$
\mathrm{W}^{(\mathrm{V})}(\mathrm{A})+\mathrm{W}^{(\mathrm{VI})}(\mathrm{B}) \stackrel{\mathrm{h} \gamma}{\rightarrow} \mathrm{W}^{(\mathrm{VI})}(\mathrm{A})+\mathrm{W}^{(\mathrm{V})}(\mathrm{B})
$$

where A and B represent tungsten sublattice knots.

This phenomenon was studied using X-ray photoelectron spectroscopy (XPS) and electron spin resonance (ESR) spectroscopy $[74,75]$. The $\mathrm{WO}_{3}$ films showed high absorption in the near-infrared region due to polaron absorption [76]. Activated $\mathrm{WO}_{3}$ films are characterized by a wide absorption band with a maximum of $0.9-1.46 \mathrm{eV}$, depending on the film properties [73]. Figure 17 shows the optical transmission spectra of $\mathrm{WO}_{3}$ (Figure 17a) and $\mathrm{WO}_{3} / \mathrm{GO}$ (Figure 17b) films upon coloring and bleaching. 


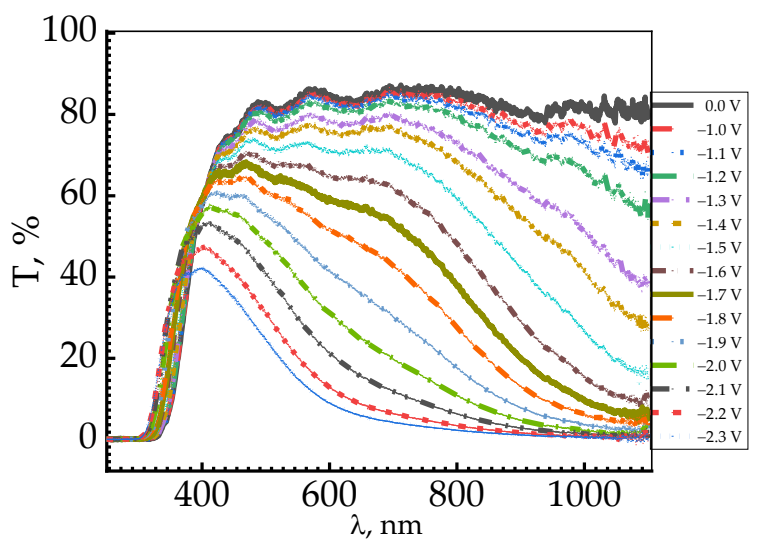

(a)

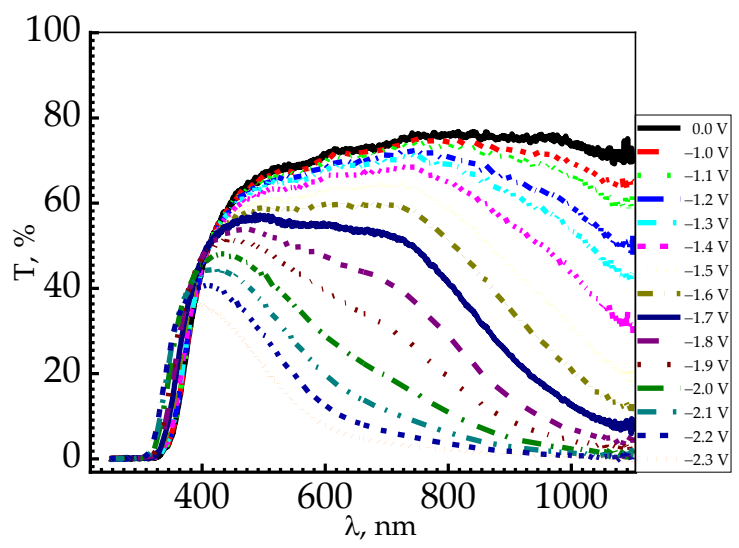

(b)

Figure 17. Optical transmission spectra of $\mathrm{WO}_{3}$ film during electrochromic response obtain by electrochemistry (cathodic) deposition: (a) $\mathrm{WO}_{3}$ at constant potential; (b) $\mathrm{WO}_{3} / \mathrm{GO}$ deposition at AC potential [77].

The optical properties of $\mathrm{WO}_{3}$ thin films depend on their structure (crystalline, polycrystalline, amorphous or hybrid). Colored and colorless states of $\mathrm{WO}_{3}$ films are not symmetric. Switching from transparent to colored states, polycrystalline $\mathrm{WO}_{3}$ films exhibit reflective properties, and amorphous $\mathrm{WO}_{3}$ films exhibit absorption properties. The switching time depends on $\mathrm{WO}_{3}$ film density and on electrolyte concentration. Low-density films with high-concentration electrolytes demonstrate the fastest switching speed [78].

Nowadays, the importance of $\mathrm{WO}_{3}$ films has grown $[79,80]$ due to their use in "Smart Windows", which smartly regulate indoor solar radiation by changing their optical transmittance, contributing to a significant reduction in a building's energy consumption (as a result of the optimization of air conditioning consumption) and helping to create comfortable indoor environments [81]. However, despite all the advantages of $\mathrm{WO}_{3}$ films, their life cycle is not very long: continuous switching between colored and colorless states causes irreversible structural changes that affect their optical and electrical properties, ultimately leading to material degradation, the so-called "aging" effect [82]. Therefore, the task of increasing the life cycle of $\mathrm{WO}_{3}$ films involves the development of new nanomaterials and/or the improvement of existing materials through the use of modificatory additives, as well as the obtained improvement of $\mathrm{WO}_{3}$ film technologies [83-86].

\section{ECD (Electrochromic Device) Structure}

EC are able to reversibly change their optical properties through the application of an electrical voltage, making them suitable for ECD, such as displays [30], electrochromic "Smart Windows" [16], anti-glare rear mirrors [19], and sensors [87].

ECD structures usually include transparent conductors, electrochromic layers, and ion conductors (Figure 18).

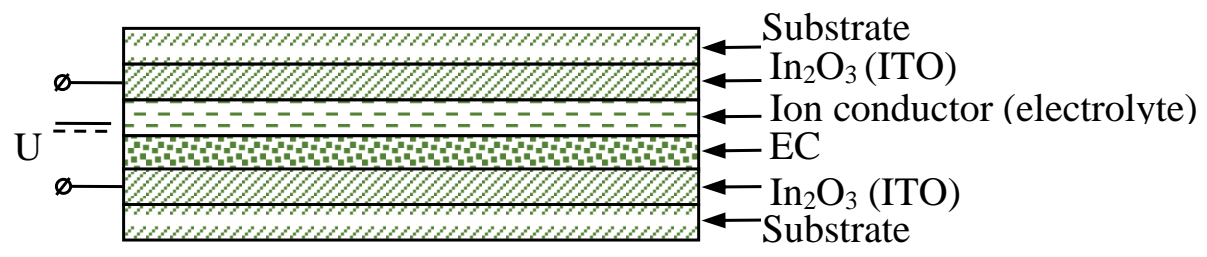

Figure 18. ECD structure.

ECD for architectural applications include thin EC films placed between two glass panels, as shown in Figures 19 and 20. 


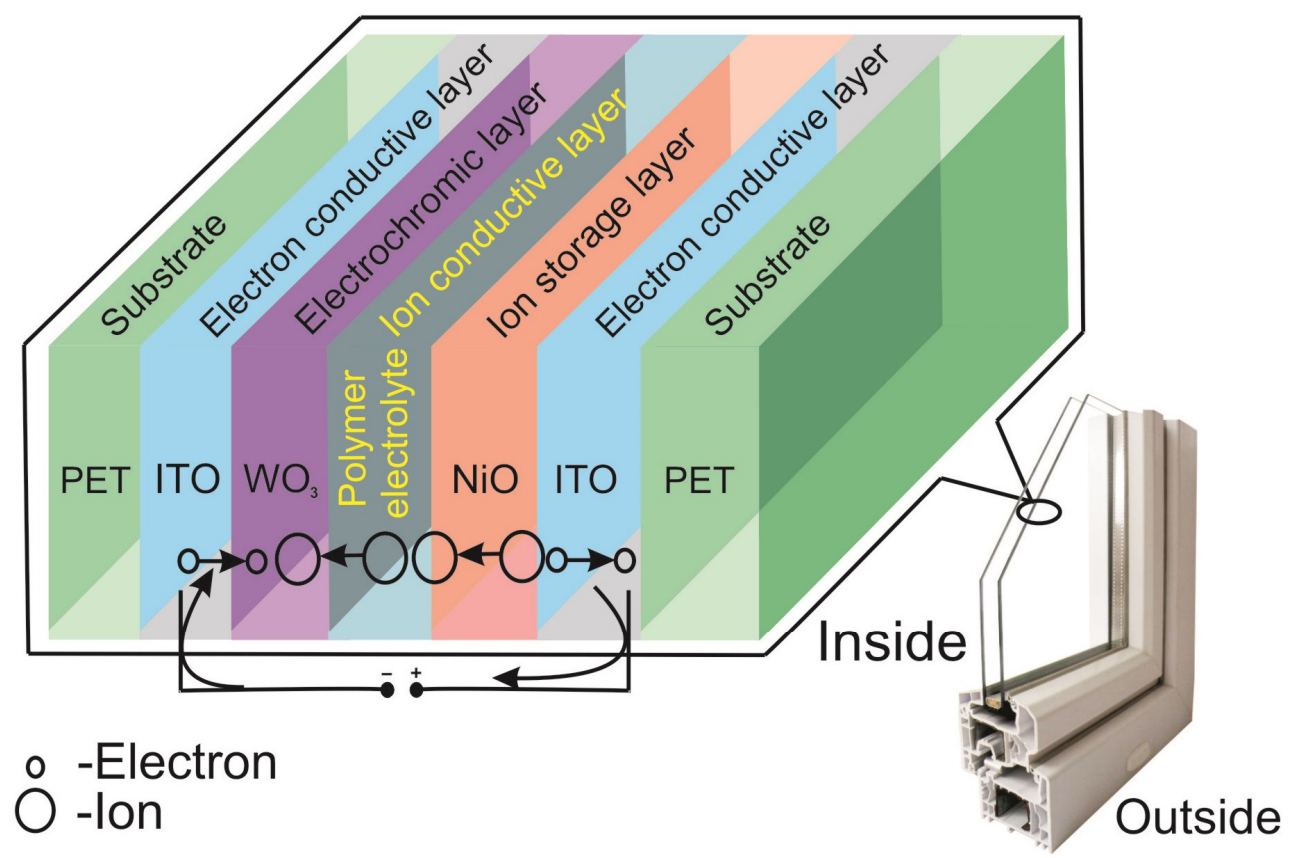

Figure 19. ECW scheme showing voltage-induced transfer of positive ions and electrons to transparent conductive layers.

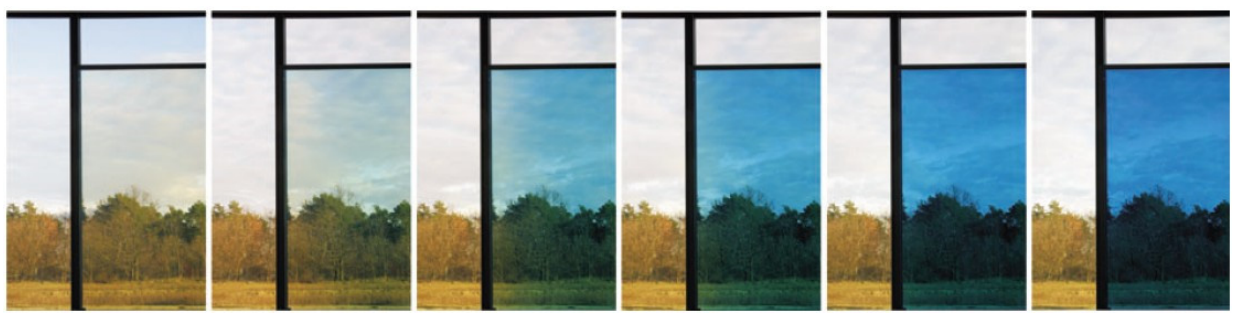

Figure 20. ECW color cycle (colored $\leftrightarrow$ semitransparent $\leftrightarrow$ transparent state).

Cycle stability is an extremely important aspect in the performance of electrochromic devices. In a recent study [88], ECD were reported to have obtained a superior longterm cycling stability of over 10,000 cycles. This manuscript is recommended for its review of some reports of devices with high long-term stability. In [89], a strategy was presented involving an all-in-one self-healing electrochromic material, TAFPy-MA, which was used for the fabrication of a high-reliability, large-scale and easy-to-assemble smart electrochromic window. The all-in-one self-healing electrochromic material was able to carry out in situ redox reactions with the $\mathrm{Li}^{+}$ions. The Diels-Alder cross-linking network structure was able to heal the cracks, improving the reliability of the electrochromic layer. Great ion diffusivity $\left(1.13 \times 10-5 \mathrm{~cm}^{2} \mathrm{~s}^{-1}\right)$, rapid color switching $(3.9 / 3.7 \mathrm{~s})$, high coloration efficiency $\left(413 \mathrm{~cm}^{2} \mathrm{C}^{-1}\right)$, excellent stability (sustain $88.7 \%$ after 1000 cycles) and reliability (crack can be healed in $110 \mathrm{~s}$ ), large-scale "Smart Windows" $\left(30 \times 35 \mathrm{~cm}^{2}\right)$ were achieved using this all-in-one electrochromic material, and these exhibited fascinating and promising features for a wide range of applications in buildings, airplanes, etc.

Electrochromic films change their color as a result of electrochemical oxidation/reduction reaction associated with ion transfer, which involves the use of an additional coating for the storage and transport of ions. Many companies offer "Smart Window" solutions; energy-saving "Smart Window" technology is available on the market [4].

Depending on the purpose, ECD may contain materials with different characteristics and properties. Figure 21 presents the classifications of ECD. 


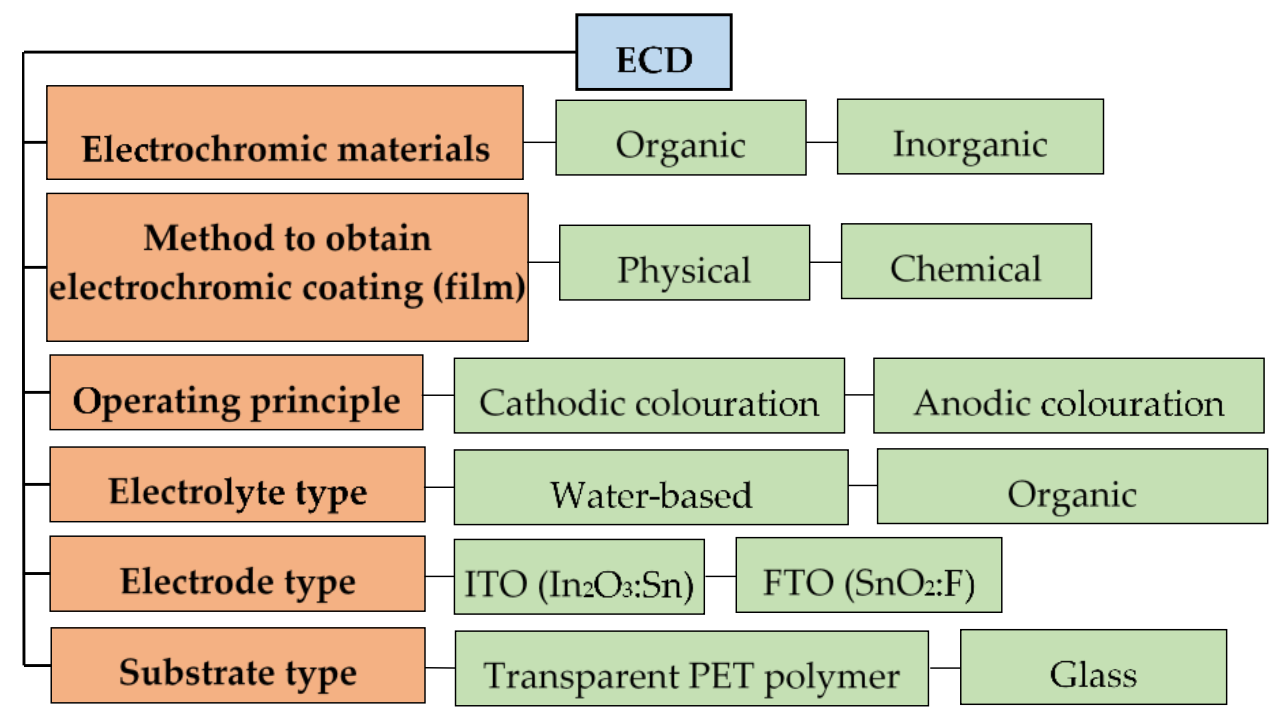

Figure 21. ECD classification.

\subsection{Substrate}

Transparent ECW substrates include glassy (Figure 22) or transparent polymers (Figure 22), such as polyethylene terephthalate (PET), polyvinyl butyral (PVB) and polyethylene naphthalate (PEN). Glass substrates are more common due to their greater transparency and their chemical stability, which makes them suitable for the production of "Smart Windows". In turn, polymer substrates allow the production costs of ECD to be reduced [90-93].

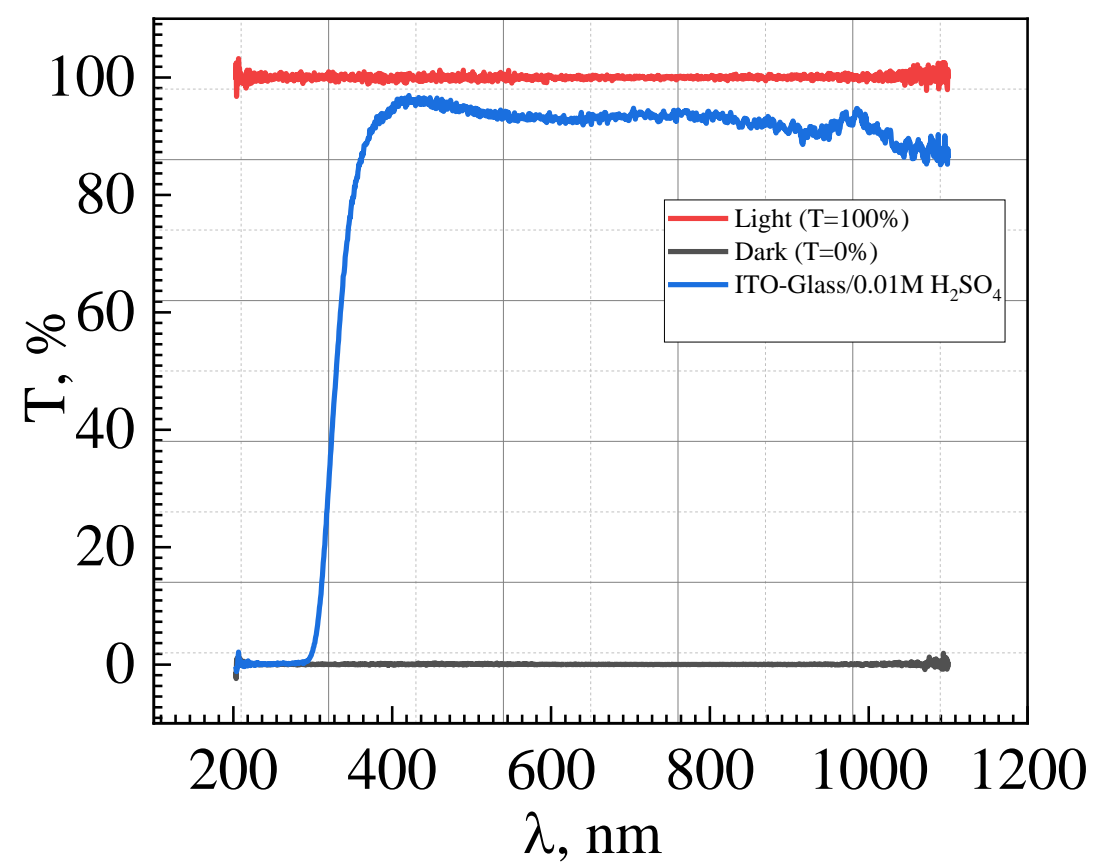

Figure 22. Visible and near-infrared transmission spectra of $\mathrm{WO}_{3}$-ITO-glass.

\subsection{Transparent Conductive Electrode}

The electrical resistivity and the light transmission coefficient are the most important properties of transparent conductive electrodes (layers). An electrode should possess high electrical conductivity in order to form the electric field required for ECD. Transparent conductive electrodes include metal-based and oxide-based electrodes, but the electrode properties should not affect the transmission properties of the electrochromic windows. Indium-tin oxide (ITO) electrodes (indium (III) oxide and tin (IV) oxide) are among the best 
transparent electrodes to have been investigated $\left(\left(\mathrm{In}_{2} \mathrm{O}_{3}\right) 0.9-\left(\mathrm{SnO}_{2}\right) 0.1: 90 \%\right.$ and $\left.10 \%\right)$ [90], possessing high electrical conductivity $\left(\sim 104 \mathrm{~S} \cdot \mathrm{sm}^{-1}\right)$ and low optical absorption (band gap $\sim 4 \mathrm{eV}$, refractive index -1.9 ), making it preferable to fluorine-doped tin oxide (FTO). Transparent ITO electrode contains different numbers of doped Sn atoms, and consequently, free electron density varies [94].

\subsection{Electrochromic Layer}

EC films reversibly change their optical properties, switching between transparent, semi-transparent and colored states, modeling solar radiation and thus ensuring reliable ECW operation. EC films (layers) can be divided into three different types according to their color schemes [32]:

- $\quad$ EC film exhibiting one color, for example, transition metal oxides, Prussian blue [31];

- $\quad$ EC film exhibiting two colors, for example, polythiophene [28];

- $\quad$ EC film exhibiting multiple colors, for example, poly (3,4-propylenedioxypyrrole) [29].

\subsection{Electrolyte (Ion Conductor)}

Electrolytes can be classified into liquid, gel and solid electrolytes [32]. Liquid electrolytes are dissolved ions. Such electrolytes provide high ionic mobility. Polymer electrolytes are the most suitable for EC devices, as they provide a long circuit break and uniformity of coloration [95].

Electrochromic device electrolytes are ionic materials that possess ionic conductivity. Electrochromic device electrolytes should satisfy the following requirements [77]:

- compatibility with anodic and cathodic materials;

- $\quad$ high ionic conductivity;

- $\quad$ no electron transfer between electrochromic layers;

- $\quad$ high transparency without scattering effect.

In [96], a novel Zn-Prussian blue (PB) system was reported for aqueous electrochromic batteries. By using different dual-ion electrolytes with various cations (e.g., $\mathrm{Zn}^{2+}-\mathrm{K}^{+}$and $\left.\mathrm{Zn}^{2+}-\mathrm{Al}^{3+}\right)$, the $\mathrm{Zn}-\mathrm{PB}$ electrochromic batteries demonstrated excellent performance. We showed that the $\mathrm{K}^{+}-\mathrm{Zn}^{2+}$ dual-ion electrolyte in the $\mathrm{Zn}-\mathrm{PB}$ configuration endowed a rapid self-bleaching time $(2.8 \mathrm{~s})$, high optical contrast $(83 \%$ at $632.8 \mathrm{~nm})$, and fast switching times $(8.4 \mathrm{~s} / 3 \mathrm{~s}$ for the bleaching/coloration processes). Remarkably, the aqueous electrochromic battery exhibited a compelling energy retrieval of $35.7 \mathrm{~mW} \cdot \mathrm{h} \cdot \mathrm{m}^{-2}$, where only $47.5 \mathrm{~mW} \cdot \mathrm{h} \cdot \mathrm{m}^{-2}$ was consumed during the round-trip coloration-bleaching process. These findings may open up new directions for the development of advanced net-zero-energyconsumption ECD.

In $[4,34,58,97]$, a hybrid electrolyte was developed based on aluminum trifluoromethanesulphonate $\left(\mathrm{Al}(\mathrm{TOF})_{3}\right)$ and $\mathrm{H}_{3} \mathrm{PO}_{4}$ that could effectively alleviate the passivation, and which exhibited superior stability. Additionally, an ex situ study revealed that the PANI cathode undergoes a process of cointercalation/deintercalation of $\mathrm{Al}\left(\mathrm{H}_{2} \mathrm{PO}_{4}^{-}\right) \mathrm{x}\left(\mathrm{TOF}^{-}\right) \mathrm{y}$ $+\left(\mathrm{H}_{2} \mathrm{O}\right) \mathrm{n}, \mathrm{TOF}^{-}$, and $\mathrm{H}^{+}$during the charging/discharging process, with high reversibility and stability. As a proof of concept, an electrochromic Al/ / PANI battery was fabricated that combined both electrochromism and energy storage and delivered a higher coloration efficiency of $84 \mathrm{~cm}^{2} \mathrm{C}^{-1}$ at a wavelength of $630 \mathrm{~nm}$.

\subsection{Counter Electrode}

The counter electrode provides ions, which, depending on the polarity of the applied voltage, are injected into or extracted from the electrochromic coating. The counter electrode should be transparent, with high conductivity, in order to reduce the voltage drop and 
prevent side reactions. Counter electrodes may include EC films, such as $\mathrm{WO}_{3} / \mathrm{PANI}$ films [98], switching from transparent to blue.

$$
\underbrace{\mathrm{WO}_{3}+\mathrm{PANI}+\mathrm{xM}^{+} \mathrm{A}^{-}}_{\text {(transparent) }} \rightleftharpoons \underbrace{\mathrm{MxWO}_{3}+(\mathrm{PANI}) \mathrm{A}_{\mathrm{x}}}_{\text {(colored) }}
$$

where $\mathrm{x}$ is the number of cations $\left(\mathrm{M}^{+}, \mathrm{H}^{+}\right)$and anions $\left(\mathrm{A}^{-}, \mathrm{SO}_{4}{ }^{-}\right)$.

Thus, thin-film electrodes broaden the ECD color palette and strengthen the electrochromic effect.

\section{5. $\mathrm{WO}_{3}$ Film Fabrication}

The $\mathrm{EC}_{\mathrm{WO}_{3}}$ layer is obtained as a thin film on a conductive substrate with an FTO or ITO electrode. There are several $\mathrm{WO}_{3}$ fabrication techniques [99] (Figure 23), including magnetron sputtering [100], electrochemical deposition [101-106], spray pyrolysis [107], sol-gel [108,109], mechanical sputtering [110,111], etc. These technologies are based on electrochemical, chemical and physical principles. C. G. Granqvist [32] provided a comprehensive survey of $\mathrm{WO}_{3}$ fabrication technologies.

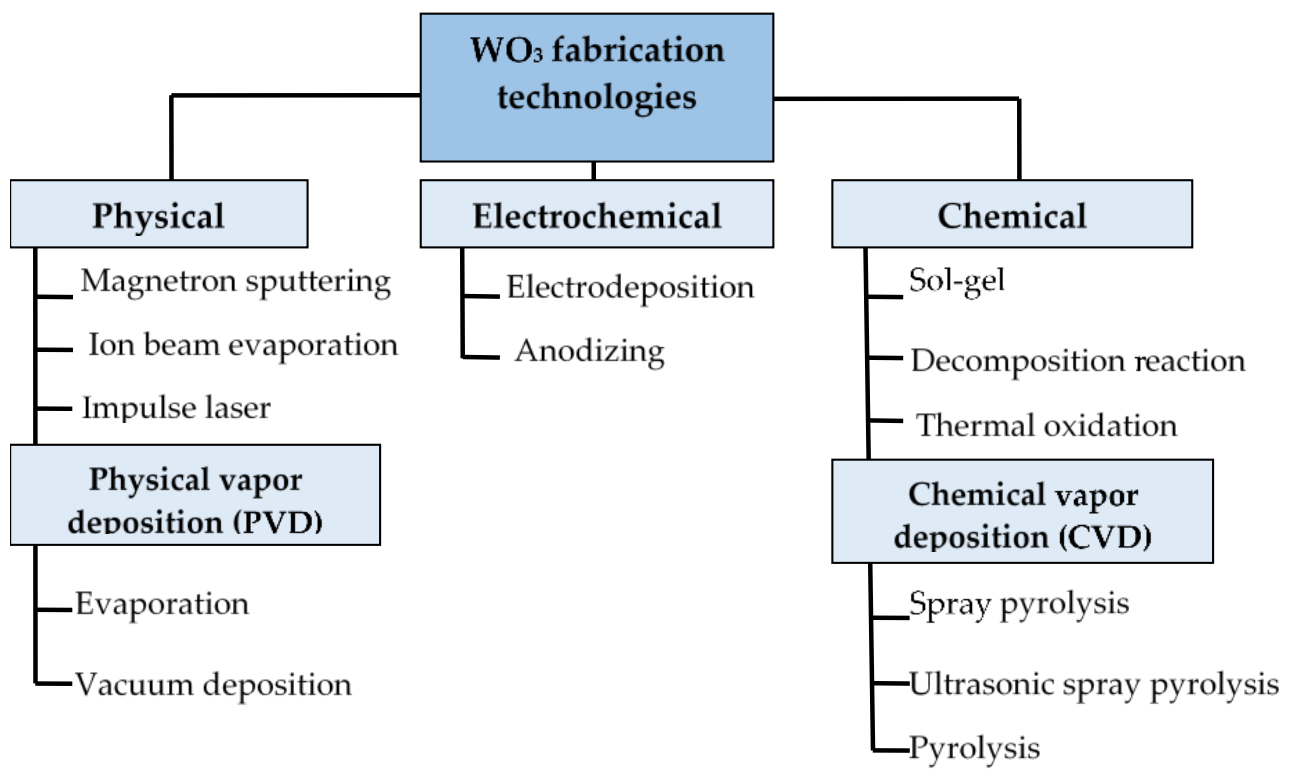

Figure 23. Classification of $\mathrm{WO}_{3}$ fabrication technologies.

Table 7 shows a comparative analysis of $\mathrm{WO}_{3}$ fabrication technologies.

Table 7. Comparison of three basic approaches to films $\mathrm{WO}_{3}$ fabrication.

\begin{tabular}{ccccc}
\hline Technology Types & Scalability & Equipment Cost & Process Costs & Coating Uniformity \\
\hline Electrochemical & $+/-$ & + & + & $+/-$ \\
\hline Chemical & $+/-$ & + & + & - \\
\hline Physical & + & - & - & + \\
\hline
\end{tabular}

The majority of technologies shown in Figure 24 are currently in use at the time of writing. Optical contrast is a key parameter for evaluating EC device quality. However, nowadays, there is no universal method that would satisfy all modern requirements. Each method has its own advantages and shortcomings. 


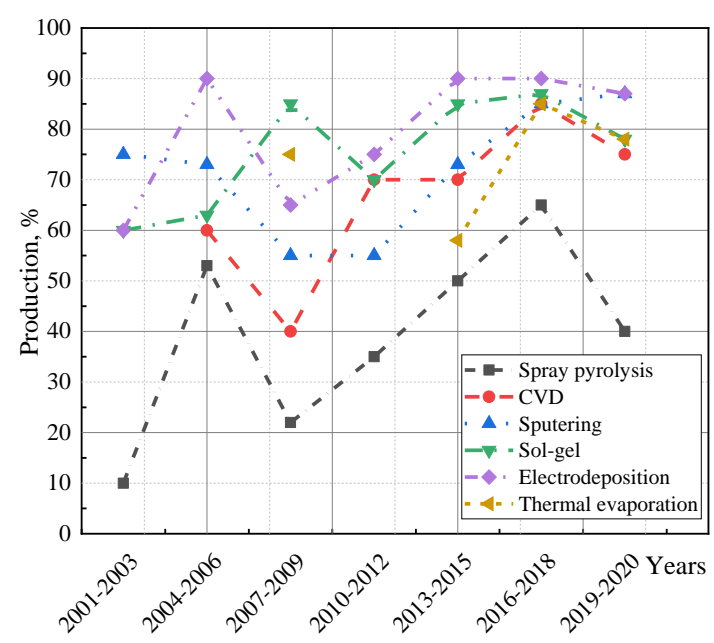

Figure 24. Contrast response curves for $\mathrm{WO}_{3}$ films obtained by different processes during the reporting period.

$\mathrm{WO}_{3}$ film characteristics include porosity, crystallinity and crystal size; these properties are highly dependent on manufacturing conditions and on production technology. The requirements for $\mathrm{WO}_{3}$ thin films include uniformity, low production cost, and long life cycle. Unfortunately, the production of a uniform $\mathrm{WO}_{3}$ film with good adhesion still remains a problem.

The vacuum deposition method makes it possible to obtain high-density $\mathrm{WO}_{3}$ films on a large flat surface, and the thickness and composition can be controlled during the deposition process [100]. Vacuum-deposited $\mathrm{WO}_{3}$ films have an amorphous structure, and annealed $\mathrm{WO}_{3}$ films have a crystalline structure. However, these technologies are highly expensive due to the expensive equipment. Many glass manufacturing companies still prefer vacuum deposition technologies, regardless of the cost, because $\mathrm{WO}_{3}$ films obtained by vacuum deposition are stable, reliable and adjustable.

Chemical vapor deposition (CVD) is used for depositing $\mathrm{WO}_{3}$ films on a substrate [112]. However, during the deposition process substrates are heated to a high temperature, which can lead to structural changes in the conductive layer. Electron beam evaporation technology is a well-known method for preparing electrochromic $\mathrm{WO}_{3}$ films [113,114].

\subsection{Electrochemical Deposition}

Electrochemical deposition (electrodeposition) is a method of low-temperature synthesis of $\mathrm{WO}_{3}$ films. Figures 25 and 26 show a three-electrode system in which conductive FTO or ITO electrodes serve as a working electrode and a platinum electrode is used as a counter electrode.

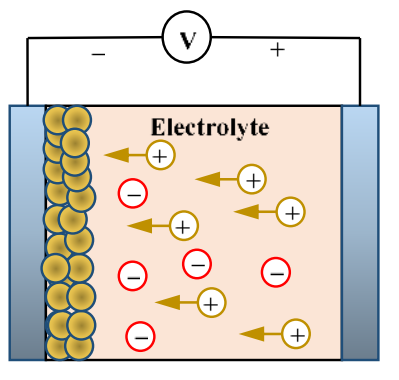

(a)

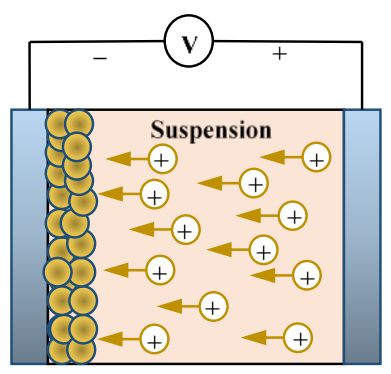

(b)

Figure 25. Two types of electrodeposition processes: (a) electroplating; (b) electrophoretic deposition. 


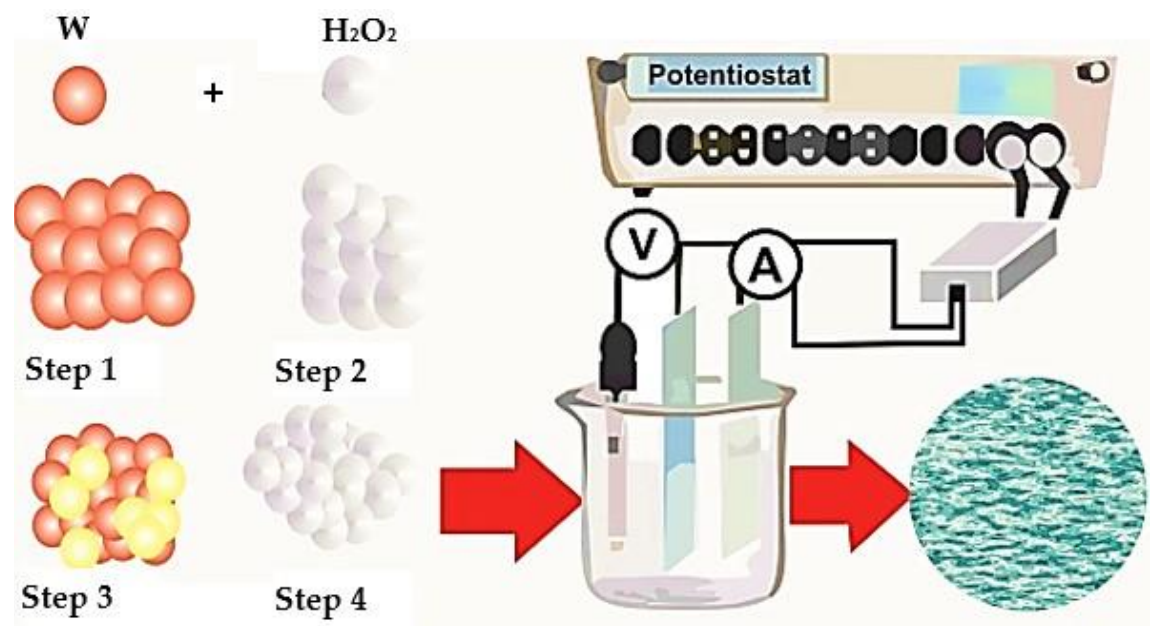

Figure 26. Growth mechanism of electrodeposited $\mathrm{WO}_{3}$ film.

The applied potential is shown relative to the reference electrode. The most common reference electrode is the silver/silver chloride $(\mathrm{Ag} / \mathrm{AgCl})$ electrode (Figure 26), due to the stability of the electrode potential.

The mechanism of electrochemical deposition of electrochromic $\mathrm{WO}_{3}$ films has been well investigated [106]; metal or precursor ions are transferred to the working electrode (cathode) under the influence of an applied electrical field. In this case, the metal deposition process can be described by the reaction:

$$
\mathrm{M}^{+}+\mathrm{e}^{-} \rightarrow \mathrm{M}
$$

As already mentioned [115,116], the electrochemical deposition method makes it possible to deposit $\mathrm{WO}_{3}$ films on large-area conductive substrates. However, special equipment is required for the deposition process. The main advantages of this method include: low cost and fast deposition, while not requiring high-temperature heating and deep vacuum.

\subsection{Sol-Gel}

Colloidal oxide can be synthesized by polycondensation, by acidification of aqueous salt solution, or by hydrolysis of organometallic compounds (Figure 27). Recently, there has been growing interest in the use of the sol-gel process to produce multilayer electrochromic coatings based on non-organic compounds. The main advantage of this reaction is that liquid compounds are converted into solid compounds [117].

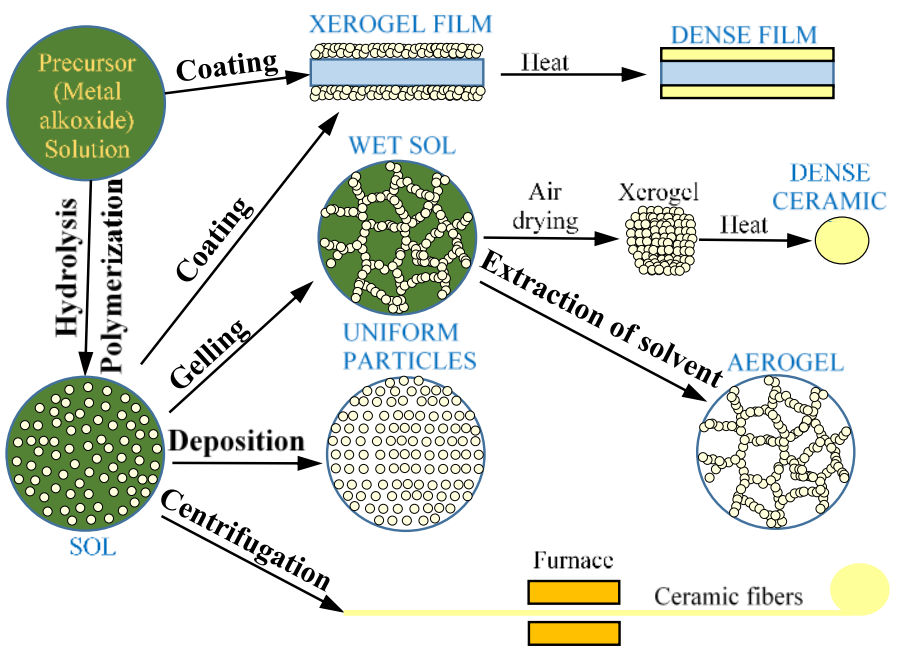

Figure 27. Sol-gel process scheme. 
Most alkoxides used for electrochromic materials can be produced in several stages [91]:

(1) hydrolysis with the formation of reactive $\mathrm{M}-\mathrm{OH}$ groups:

$$
\mathrm{M}-\mathrm{OR}+\mathrm{H}_{2} \mathrm{O} \rightarrow \mathrm{M}-\mathrm{OH}+\mathrm{ROH}
$$

(2) condensation resulting in bridge oxygen formation:

$$
\begin{aligned}
& \mathrm{M}-\mathrm{OH}+\mathrm{RO}-\mathrm{M} \rightarrow \mathrm{M}-\mathrm{M}+\mathrm{ROH} \\
& \mathrm{M}-\mathrm{OH}+\mathrm{HO}-\mathrm{M} \rightarrow \mathrm{M}-\mathrm{M}+\mathrm{H}_{2} \mathrm{O}
\end{aligned}
$$

There are different types of sol-gel processes, such as centrifugation, immersion coating and spraying (Figure 28). The sol-gel method, widely applied in material synthesis, is also used to modify the electrode surface [118].

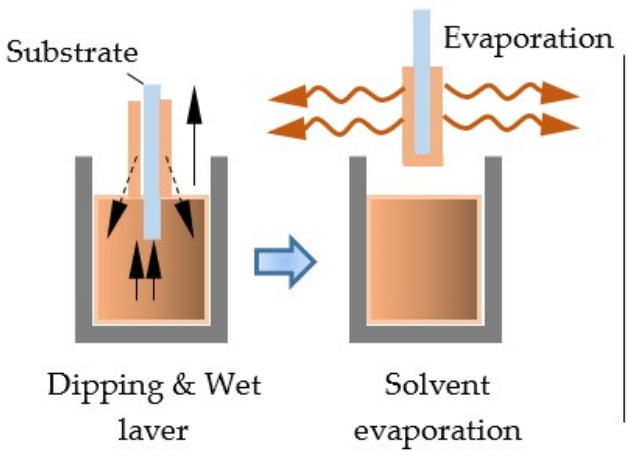

(a)

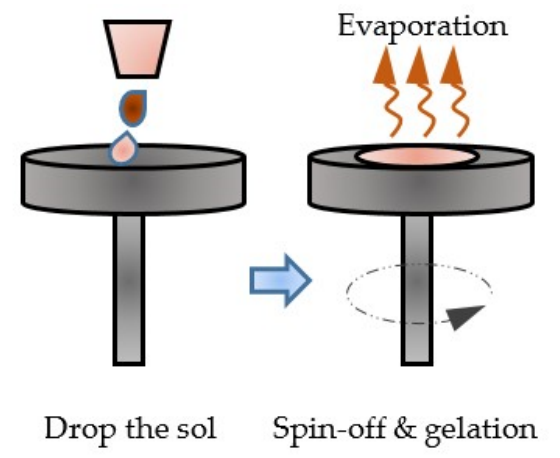

(b)

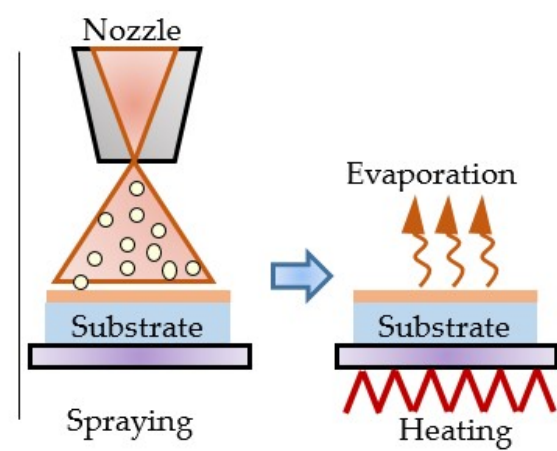

(c)

Figure 28. Types of sol-gel processes: (a) immersion coating; (b) centrifugation; (c) spraying.

Sol-gel methods make it possible to produce large-area $\mathrm{WO}_{3}$ films at lower cost in comparison with traditional vacuum methods [119]. The advantages of this method include: universality of sol-gel processes, easy control of microstructure and composition under low-temperature conditions, relatively simple and inexpensive equipment, control of microstructure, crystal size, porosity and composition of the deposited films, which is important, since these characteristics affect thin film kinetics, durability and staining efficiency [120]. However, many problems still remain to be solved, among them solution stability, large-area uniformity, insufficient adhesion, insufficient film thickness, and low repeatability.

\subsection{Spray Pyrolysis}

The main principle of spray pyrolysis is the pyrolytic decomposition of salt solution sprayed on substrate consisting of deposition target material (Figure 29). The sprayed solution undergoes pyrolytic decomposition and forms a crystallite or a crystallite cluster when the drop comes into contact with the hot substrate surface. 


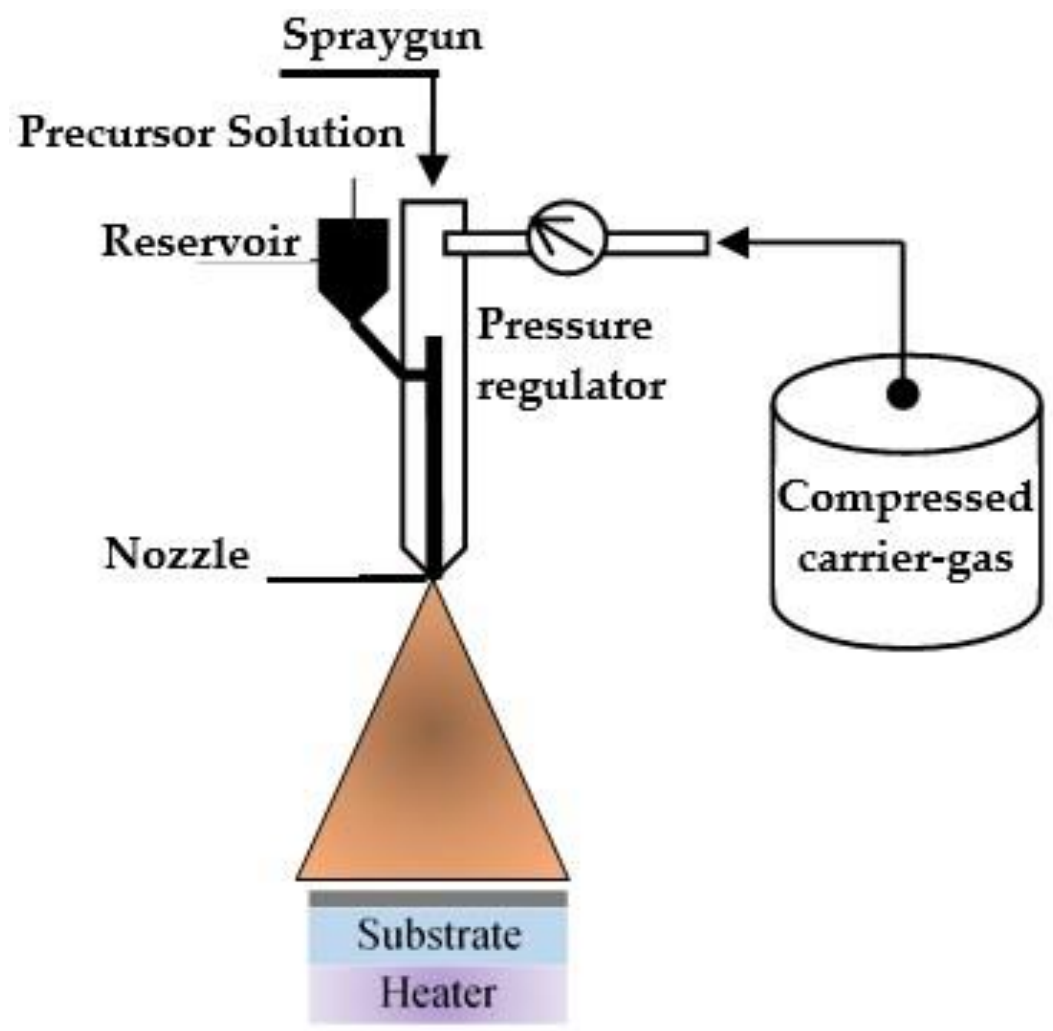

Figure 29. Pyrolytic deposition of EC films.

By-products and solvents evaporate during spraying. The hot substrate provides thermal energy for thermal decomposition. After thermal decomposition, sintering and crystallization of the crystallite clusters occur, ultimately leading to film formation. The technique is used for the deposition of dense and porous films on different substrates, such as glass, ceramics and metal.

Spray pyrolysis is a simple and relatively inexpensive method that does not require a vacuum. This method allows large-area uniform films with good adhesion to be produced. Moreover, film properties can be easily modified by changing the spray parameters, such as substrate temperature, flow pressure and the molarity of the precursor solution. The main advantage of this method is that it works at moderate temperatures $\left(100-500{ }^{\circ} \mathrm{C}\right)$ and allows films to be obtained even on low-quality substrates. It offers an easy way of doping films with any elements in any proportion by adding them in some form to the spray solution [121,122]. In [123], $\mathrm{V}_{2} \mathrm{O}_{5}-\mathrm{WO}_{3}$ composite films were reported to exhibit high coloration efficiency $\left(49 \mathrm{~cm}^{2} \cdot \mathrm{C}^{-1}\right)$. Ref. [124], a fibrous reticulated $\mathrm{WO}_{3}$ film obtained by pulsed spray pyrolysis was reported to have a coloration efficiency of $34 \mathrm{~cm}^{2} \cdot \mathrm{C}^{-1}$ at $\lambda=$ $630 \mathrm{~nm}$.

Spray pyrolysis is a cost-effective method for obtaining highly adhesive homogeneous $\mathrm{WO}_{3}$ films with different microstructures. The technology can also be used to produce multilayer films, which is achieved by varying the spray composition. However, this method also has disadvantages, such as the non-uniformity of films, large grain size due to uncontrolled sputtering, solvent loss, and low deposition rate. The mentioned advantages of the spray pyrolysis method make it suitable for industrial applications.

\subsection{Magnetron Sputtering}

Magnetron sputtering is a deposition technology defined as "cathodic sputtering of target material in magnetron discharge plasma (crossed field discharge)", and is shown in Figure 30. 


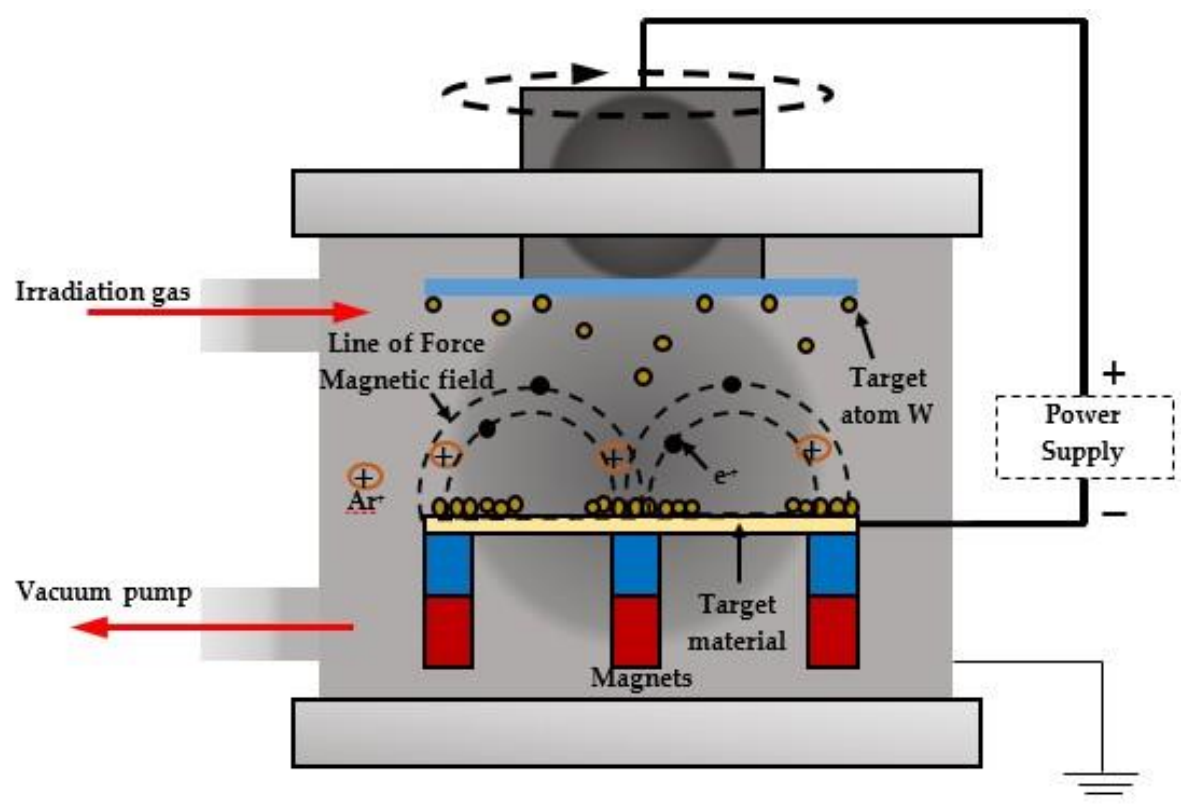

Figure 30. Magnetron sputtering apparatus (working principal).

In this process, permanent magnets are arranged below the target plate so as to produce a magnetic field close to the target material. This concentrates the electrons and causes them to travel in a spiral fashion along the magnetic flux lines of the target instead of wandering around the target material [100].

Magnetron sputtering is the most up-to-date deposition technology [99,100], and is widely used in the industrial and scientific spheres. The frequency of the applied positive DC voltage varies from 20 to $350 \mathrm{kHz}$, while reversed pulse duration is dependent on dielectric surface discharge [125]. Negative voltage usually varies by an amount equivalent to $10 \%$ of the average positive voltage. When the duration and number of positive voltage pulses are sufficient to create electric current, the target surface is bombarded with ions, and when the voltage becomes negative, the incoming ions are repelled. Chen [126,127] investigated $\mathrm{WO}_{3}$ films deposited by pulsed magnetron sputtering at a constant frequency of $70 \mathrm{kHz}$; the $\mathrm{O}_{2} /$ Ar ratio was reported to vary from 0.2 to 1.0 .

The disadvantages of this method include the expensive equipment required and the high energy intensity, which significantly increases ECD cost. The magnetron sputtering technique is used to produce FTO or ITO electrodes on transparent surfaces.

\section{Nanomaterials for Electrochromic Devices}

ECW control the transmittance of light and solar radiation by changing their optical transmittance (transparent, semitransparent and colored states), which ensures comfortable indoor environments and makes it possible to achieve energy savings in buildings. Recent advances in ECD technology emerging in the 1970s led to the creation of different types of ECD. However, there are still problems with respect to the commercialization of EC devices, including aspects such as their high production cost [99], the stability of their long-term operation, and the production of uniform electrochromic films to provide uniformity of coloration in large-area ECW [28-32]. Nanotechnologies can be efficiently used to produce low-cost high-performance ECD [128].

In [129], an experiment was described in which reduced graphene oxide (rGO) films were electrodeposited on indium tin-oxide-coated polyethylene terephthalate substrates (ITO-PET) from graphene oxide (GO), and the resulting flexible transparent electrodes were used in ethyl viologen $\left(\mathrm{EtV}^{+}\right)$electrochromic devices. During continuous testing, the resulting devices, which contained GO/rGO in the electrochromic mixture, exhibited a lower switching voltage between the colored and bleached states. Graphene oxide (GO) 
and reduced graphene oxide ( $\mathrm{rGO}$ ) enabled devices with higher optical contrast than those free of $\mathrm{GO}$ at the same applied voltage.

In [130], $\mathrm{WO}_{3} / \mathrm{rGO}$ nanocomposite film was fabricated by sol-gel centrifugation using a mixed colloidal dispersion of $\mathrm{WO}_{3}$ precursor and GO. It was reported that the $\mathrm{WO}_{3} / \mathrm{rGO}$ nanocomposite film exhibited shorter coloration and bleaching times $\left(\mathrm{T}_{\mathrm{C}}=9.5 \mathrm{~s}\right.$ and $\left.\mathrm{T}_{\mathrm{b}}=7.6 \mathrm{~s}\right)$, higher coloration efficiency $\left(75.3 \mathrm{~cm}^{2} \cdot \mathrm{C}^{-1}\right.$ at $\left.633 \mathrm{~nm}\right)$, larger optical modulatory range $(59.6 \%$ at $633 \mathrm{~nm})$ and better cyclic stability compared with $\mathrm{WO}_{3}$ films; these advantages were attributed to faster $\mathrm{Li}^{+}$ion diffusion and electron transfer rate.

Optically adjustable electrochromic films are basic and important components of electrochromic devices; therefore, the performance of EC devices is strongly dependent on EC film structure, morphology and fabrication method [131].

Amorphous $\mathrm{WO}_{3}$ films have a porous structure. Crystalline $\mathrm{WO}_{3}$ exhibits better durability compared to amorphous $\mathrm{WO}_{3}$, due to its denser structure and low dissolution rate (stability in acidic solution is less than $4 \mathrm{pH}$ ) [93,94,132]. However, crystalline $\mathrm{WO}_{3}$ possesses high bulk density, which increases switching time and reduces coloring efficiency, so nanostructured $\mathrm{WO}_{3}$ with a large specific surface area is expected to have a faster response time and a good durability. Recently, publications have appeared $[105,133]$ on the use of nanoscale or nanoporous $\mathrm{WO}_{3}$ (Figure 31) that exhibit fast switching speed and high coloration efficiency due to possessing a good and suitable band gap ( 2.6 eV). In [134-136] the technologies for producing nanostructured $\mathrm{WO}_{3}$ films are discussed (Figure 32).
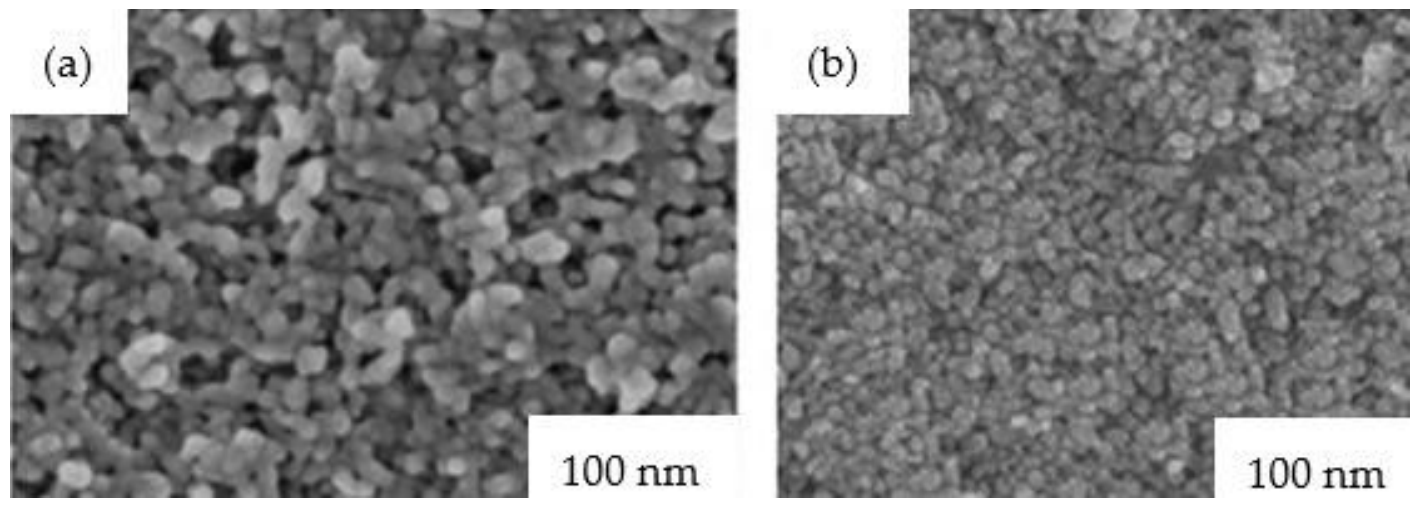

Figure 31. FE-SEM micrographs for nc- $\mathrm{TiO}_{2}$ nanoparticles film: (a) before deposition; (b) deposited on $\mathrm{H}_{2} \mathrm{~W}_{2} \mathrm{O}_{11}$ electrolyte surface.

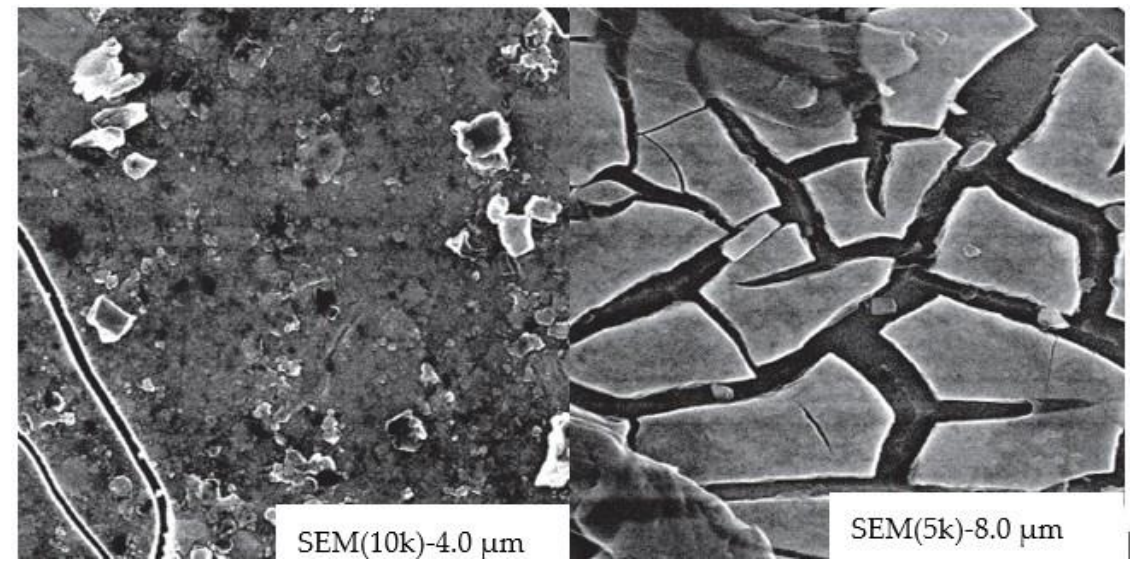

(a)

(b)

Figure 32. Nanostructured films obtained by electrochemical deposition: (a) $\mathrm{WO}_{3}\left(\mathrm{GO}_{2 \mathrm{~mL}}\right)$; (b) $\mathrm{WO}_{3}\left(\mathrm{GO}_{1 \mathrm{~mL}}\right)[135]$. 
Nanocrystal-in-glass $\mathrm{WO}_{3}$ thin films are considered to be the most promising cathodic electrochromic material [113]. In [137], an all-solution technology was developed for largearea low-cost preparation of electrochromic films. $\mathrm{A} \mathrm{WO}_{3} / \mathrm{ITO}$ dispersion was successfully developed; high-electrical-conductivity ITO nanoparticle networks along with ITO coating on glass were able to serve as extended 3-dimensional electrodes, forming a microelectrical field and acting as the pathways for electron diffusion to $\mathrm{WO}_{3}$ nanorods. In [138], h- $\mathrm{WO}_{3}$ QDs with an average size of $1.2 \mathrm{~nm}$ were successfully prepared by a simple decomposition process of tungsten acid in ethylene glycol.

At present, various interactions have been introduced at the interface between the organic and inorganic phases. The expected improved electrochemical and electrochromic performances of the nanocomposites have been obtained. Among of these interactions, covalent bonds have the strongest interaction, although their preparation is relatively complicated [131,138].

Thus, it is an important first step for the fabrication of inexpensive EC "Smart Windows", and should shape the future research on solution-based processes.

\section{Conclusions}

It was possible, within the scope of this article, to provide a comprehensive review of the large area of new electrochromic materials, and the authors had to use their discretion in choosing up-to-date findings to illustrate this exciting area.

In summarizing this review of the literature on electrochromism in electrochromic materials, and in $\mathrm{WO}_{3}$ films in particular, the following conclusions can be drawn:

(1) There are several hypotheses concerning the mechanism of electrochromism in $\mathrm{WO}_{3}$. Generally, the electrochromic effect in $\mathrm{WO}_{3}$ films can be described as an electrochemical cathodic polarization during which $\mathrm{H}^{+}$ions are transferred from the electrolyte and an electron is transferred from the ITO electrode. As a result, $\mathrm{WO}_{3}$ film switches from a bleached to a colored state; its color varies from pale blue to dark blue and black. The conductivity of $\mathrm{WO}_{3}$ films is determined by the presence of cations $\left(\mathrm{H}^{+}\right.$, $\mathrm{Li}^{+}$, etc.) and electrons. As already mentioned, the coloration mechanism in $\mathrm{WO}_{3}$ films has still been insufficiently investigated.

(2) Despite a large number of works devoted to the study of electrochromic $\mathrm{WO}_{3}$ films, the influence of the structural state on optical properties during the electrochemical reaction has not been fully investigated. Different film deposition techniques have been proposed. Film morphology is dependent on deposition technique and can be amorphous, crystalline, nanocrystalline or hybrid. Additionally, there is still a constant need for new technologies to produce $\mathrm{WO}_{3}$ films, and nanostructured $\mathrm{WO}_{3}$ films in particular. Therefore, there is a necessity to study the fabrication of amorphous, crystalline and nanocrystalline $\mathrm{WO}_{3}$ films, including their $\mathrm{GO} / \mathrm{rGO}$ modification. Analysis of literary sources makes it possible to identify prospects for the development of $\mathrm{WO}_{3} / \mathrm{rGO}$ fabrication technologies. The obtained data will be useful in the development of $\mathrm{WO}_{3}$ fabrication technologies.

Today, the development of the energy-efficient glazing sector is impossible without EC Modern nanomaterials make ECD an interesting commercial product that has obvious advantages over its competitors, such as PDLC, LCD and SPD. In this regard, according to some forecasts, the market for electrochromic "Smart Window" will expand in the next 5-7 years. First of all, thanks to the development of modern technologies and nanomaterials, as well as intensive research into EC by companies and scientific laboratories around the world.

Author Contributions: Conceptualization, A.V.S. (Aleksei Viktorovich Shchegolkov), A.V.S. (Alexandr Viktorovich Shchegolkov) and S.-H.J.; methodology, M.S.L. and A.V.S. (Aleksei Viktorovich Shchegolkov); validation, Y.V.R. and A.O.S.; formal analysis, S.-H.J.; investigation, M.S.L. and A.V.S. (Aleksei Viktorovich Shchegolkov); resources, S.-H.J.; writing-original draft preparation, Y.V.R. and A.O.S.; writing-review and editing, A.V.S. (Aleksei Viktorovich Shchegolkov) and A.V.S. (Alexandr Vik- 
torovich Shchegolkov); visualization, A.V.S. (Aleksei Viktorovich Shchegolkov); supervision, A.V.S. (Aleksei Viktorovich Shchegolkov), A.V.S. (Alexandr Viktorovich Shchegolkov) and S.-H.J.; project administration, A.V.S. (Aleksei Viktorovich Shchegolkov); funding acquisition, S.-H.J. All authors have read and agreed to the published version of the manuscript.

Funding: This work was supported by the National Research Foundation (NRF) grant funded by the Korea government (MSIT) (No. 2020R1C1C1005273, 2021M3H4A02056037).

Institutional Review Board Statement: Not applicable.

Informed Consent Statement: Not applicable.

Data Availability Statement: The data presented in this study are available on request from the corresponding author.

Conflicts of Interest: The authors declare no conflict of interest.

$\begin{array}{ll}\text { Abbreviations } \\ \text { EC } & \text { electrochromic materials; } \\ \text { PhC } & \text { photochromic materials; } \\ \text { ThC } & \text { thermochromic materials; } \\ \text { GhC } & \text { gasochromic materials; } \\ \text { PDLC } & \text { polymer-dispersed liquid crystals; } \\ \text { LDC } & \text { liquid crystal dispersions; } \\ \text { ECD } & \text { electrochromic devices; } \\ \text { ECW } & \text { electrochromic windows; } \\ \text { TMO } & \text { transition metal oxides; } \\ \text { GO } & \text { graphene oxide; } \\ \text { rGO } & \text { reduced graphene oxide; } \\ \text { SPD } & \text { suspended particles; } \\ \text { EMR } & \text { electromagnetic radiation. }\end{array}$

\section{References}

1. Addington, D.M.; Schodek, D.L. Smart Materials and New Technologies for the Architecture and Design Professions; Elsevier Science: Oxford, UK, 2005; p. 241.

2. Granqvist, C.G.; Green, S.; Niklasson, G.A.; Mlyuka, N.R.; Kraemer, S.; Georén, P. Advance in chromogenic materials and devices. Thin Solid Film. 2010, 518, 3046-3053. [CrossRef]

3. Bamfield, P. Chromic Phenomena the Technological Applications of Colour Chemistry; Royal society of Chemistry (RSC): Cambridge, UK, 2001; p. 374.

4. Baetens, R.; Jelle, B.P.; Gustavsen, A. Properties, requirements and possibilities of smart windows for dynamic daylight and solar energy control in buildings: A state-of-the art review. Sol. Energy Mater. Sol. Cells 2010, 94, 87-105. [CrossRef]

5. Aoul, K.T.; Attoye, D.; Al Ghatrif, L. Perfomance of electrochromic glazing: State of the art review. In 4th International Conference on Civil Engineering and Materials Science (ICCEMS 2019), Proceedings of the IOP Conference Series Materials Science and Engineering, Bangkok, Thailand, 17-19 May 2019; IOP Publishing: Bristol, UK, 2019; Volume 603, p. 22085. [CrossRef]

6. Pacheco-Torgal, F.; Rasmussen, E.; Granqvist, C.-G.; Ivanov, V.; Kaklauskas, A.; Makonin, S. Start-Up Creation: The Smart Eco-Efficient Built Environment; Woodhead Publishing: Sawston, UK, 2016; p. 510. [CrossRef]

7. Somani, P.R.; Radhakrishman, S. Electrochromic materials and devices: Present and future. Mater. Chem. Phys. 2002, 77, 117-133. [CrossRef]

8. Aburas, M.; Soebarto, V.; Williamson, T.; Liang, R.; Ebendorff-Heidepriem, H.; Wu, Y. Thermochromic smart window technologies for building application: A review. Appl. Energy 2019, 255, 113522. [CrossRef]

9. Wittwer, V.; Datz, M.; Ell, J.; Georg, A.; Graf, W.; Walze, G. Gasochromic windows. Sol. Energy Mater. Sol. Cells 2004, 84, 305-314. [CrossRef]

10. Zhao, Y.; Ikeda, T. Smart Light-Responsive Materials: Azobenze-Containing Polymers and Liquid Crystals; John Wiley \& Sons: Hoboken, NJ, USA, 2009; p. 514. [CrossRef]

11. Lampert, C.M. Chromogenic smart materials. Mater. Today 2004, 7, 28-35. [CrossRef]

12. Granqvist, C.G.; Lansaker, P.C.; Mlyuka, N.R.; Niklasson, G.A.; Avendano, E. Progress in chromogenics: New results for electrochromic and thermochromic materials and devices. Sol. Energy Mater. Sol. Cells 2009, 93, 2032-2039. [CrossRef]

13. Rauh, R.D.; Wang, F.; Reynolds, J.R.; Mecker, D.L. High coloration efficiency electrochromics and their application to multi-color devices. Electrochim. Acta 2001, 46, 2023-2029. [CrossRef] 
14. Svensson, J.S.E.M.; Granqvist, C.G. Electrochromic coatings for "Smart Windows". Sol. Energy Mater. 1985, 12, 391-402. [CrossRef]

15. Clayton, R.P. Introduction to Electromagnetic Compatibility; John Wiley \& Sons: Hoboken, NJ, USA, 2006 ; p. 1013.

16. Lampert, C.M. Large-area smart glass and integrated photovoltaics. Sol. Energy Mater. Sol. Cells 2003, 76, 489-499. [CrossRef]

17. Deb, S.K. A novel electrophotographic system. Appl. Opt. 1969, 8, 192-195. [CrossRef]

18. Deb, S.K. Optical and photoelectric properties and colour centres in thin films of tungsten oxide. Philos. Mag. 1973, 27, 801-822. [CrossRef]

19. Gao, W.; Lee, S.H.; Bullock, J.; Xu, Y.; Benson, D.K.; Morrison, S.; Branz, H.M. Photovoltaic-powered monolithic tandem electrochromic smart window device. Sol. Energy Mater. Sol. Cells. 1999, 59, 243-254. [CrossRef]

20. Niklasson, G.A.; Berggren, L.; Jonsson, A.K.; Ahuja, R.; Skorodumova, N.V.; Backholm, J.; Stromme, M. Electrochemical studies of the electron states of disordered electrochromic oxides. Sol. Energy Mater. Sol. Cells 2006, 90, 385-394. [CrossRef]

21. Beaujuge, P.M.; Reynolds, J.R. Color control in $\pi$-conjugated organic polymers for use in electrochromic devices. Chem. Rev. 2010, 110, 268-320. [CrossRef]

22. Ferara, M.; Bengisu, M. Materials that Change Color—Smart Materials Intelligent Design; Springer: Berlin/Heidelberg, Germany, 2014; p. 145. [CrossRef]

23. Kraft, A. Electrochromism: A fascinating branch of electrochemistry. ChemText 2019, 5, 1-18. [CrossRef]

24. Pettersson, H.; Gruszecki, T.; Johansson, L.-H.; Edwards, M.O.M.; Hagfeldt, A.; Matuszczyk, T. Direct-driven electrochromic displays based on nanocrystalline electrodes. Displays 2004, 25, 223-230. [CrossRef]

25. Murphy, M.; Gustavsen, A.; Jelle, B.P.; Haase, M. Energy savings potential with electrochromic switchable glazing. In Proceedings of the 9th Nordic Symposium on Building Physics, Tampere, Finland, 29 May-2 June 2011; Volume 3, pp. $1281-1288$.

26. Lampert, C.M. Electrochromic materials and devices for energy efficient windows. Sol. Energy Mater. 1984, 11, 1-27. [CrossRef]

27. Rauh, R.D. Electrochromic windows: An overview. Electrochim. Acta 1999, 44, 3165-3176. [CrossRef]

28. Mortimer, R.J. Organic electrochromic materials. Electrochim. Acta 1999, 44, 2971-2981. [CrossRef]

29. Mortimer, R.J. Electrochromic materials. Annu. Rev. Mater. Res. 2011, 41, 241-268. [CrossRef]

30. Rowley, N.M.; Mortimer, R.J. New electrochromic materials. Sci. Prog. 2002, 85, 243-262. [CrossRef]

31. Granqvist, C.G.; Pehlivan, I.B.; Green, S.V.; Lansaker, P.C.; Niklasson, G.A. Oxide-based electrochromics: Advances in materials and devices. Mater Res. Soc. Symp. Proc. 2011, 1328, 11-22. [CrossRef]

32. Granqvist, C.G. Handbook of Inorganic Electrochromic Materials; Elsevier Science: Amsterdam, The Netherlands, $1995 ;$ p. 650.

33. Argum, A.A.; Aubert, P.-H.; Thompson, B.C.; Scwebdeman, I.; Gaupp, C.L.; Hwang, J.; Pinto, H.J.; Tanner, D.B.; MacDiarmid, A.G.; Reynolds, J.R. Multicolored electrochromism in polymers structures and devices. Chem. Mater. 2004, 16, $4401-4412$. [CrossRef]

34. Jelle, B.P.; Hagen, G.; ØdegÅrd, R. Transmission spectra of an electrochromic window based on Polyaniline, Tungsten Oxide and a solid polymer electrolyte. Electrochim. Acta 1992, 37, 1377-1380. [CrossRef]

35. Chang, I.F. Electrochromic and electrochemichromic materials and phenomena. In Nonemissive Electooptic Displays; Springer: New York, NY, USA, 1976; pp. 155-196. [CrossRef]

36. Chang, I.F.; Gilbert, B.L.; Sun, T.I. Electrochemichromic systems for display applications. J. Electrochem. Soc. 1975, 122, 955-962. [CrossRef]

37. Zou, Y.S.; Zhang, Y.C.; Lou, D.; Wang, H.P.; Gu, L.; Dong, Y.H.; Dou, K.; Song, X.F.; Zeng, H.B. Structural and optical properties of $\mathrm{WO}_{3}$ films deposited by pulsed laser deposition. J. Alloy. Compd. 2014, 583, 465-470. [CrossRef]

38. Zhang, G.; Lu, K.; Zhang, X.; Yuan, W.; Shi, M.; Ning, H.; Tao, R.; Liu, X.; Yao, R.; Peng, J. Effects of annealing temperature on optical band gap of sol-gel tungsten trioxide films. Micromachines 2018, 9, 377. [CrossRef]

39. Bohnke, O.; Bohnke, C.; Robert, G. Electrochromism in $\mathrm{WO}_{3}$ thin films. I. $\mathrm{LiClO}_{4}$-Propylene Carbonate-Water electrolyres. Solid State Ion. 1982; 6, 121-128. [CrossRef]

40. Wei, C.; He, J.; Dettelbach, K.E.; Johnson, N.J.J.; Sherbo, R.S.; Berlinguette, C.P. Photodeposited amorphous oxide films for electrochromic windows. Chem 2018, 4, 821-832. [CrossRef]

41. Saxena, A.P.; Deepa, M.; Joshi, A.G.; Bhandari, S.; Srivastava, A.K. Poly(3,4-ethylenedioxythiophene)-Ionic Liquid Functionalized Graphene/Reduced Graphene Oxide Nanostructures: Improved Conduction and Electrochromism. ACS Appl. Mater. Interfaces 2011, 3, 1115-1126. [CrossRef] [PubMed]

42. Bange, K. Colouration of tungsten oxide films: A model for optically active coatings. Sol. Energy Mater. Sol. Cells 1999, 58, 1-131. [CrossRef]

43. Granqvist, C.G. Electrochromic tungsten oxide films: Review of progress. Sol. Energy Mater. Sol. Cells 2000, 60, 201-262. [CrossRef]

44. Callister, W.D.; Rethwisch, D.G. Materials Science and Engineering-An Introduction; John Wiley \& Sons Inc.: Hoboken, NJ, USA, 2019; p. 1000.

45. Monk, P.M.S. The Viologens: Physicochemical Properties, Synthesis and Applications of the Salts of 4,4'-Bipyrindine; Wiley: Chichester, UK, 1998; p. 332.

46. Grant, B.; Clecak, N.J.; Oxsen, M.; Jaffe, A.; Keller, G.S. Study of the electrochromism of methoxyflurene compounds. J. Org. Chem. 1980, 45, 702-705. [CrossRef]

47. Rosseinsky, D.R.; Monk, P.M.S.; Hann, R.A. Anion-dependent aqueous electrodeposition of electrochromic 1,1'-bis-cyanophenyl4,4'-bipyridilium (cyanophenylparaquat) radical cation by cyclic voltammetry amd spectrochemical studies. Electrochim. Acta 1990, 35, 1113-1123. [CrossRef] 
48. Rosseinsky, D.R.; Monk, P.M.S. Electrochromic cyanophenylparaquat (CPQ: 1,1'-bis-cayanophenyl-4,4'-bipyridilium) studied voltammetrically, spectroelectrochemically and by ESR. Sol. Energy Mater. Sol. Cells 1992, 25, 201-210. [CrossRef]

49. Kanagarj, M.; Velayutham, D.; Suryanarayanan, V.; Kathiresan, M.; Ho, K.-C. Viologen based electrochromic materials and devices. J. Mater. Chem. C 2019, 7, 4622-4637. [CrossRef]

50. Gadgil, B.; Damlin, P.; Heinonen, M.; Kvarnström, C. A facile one step electrostatically driven electrodeposition of polyviologenreduced grapheme oxide nanocomposite films for enhanced electrochromic performance. Carbon 2015, 89, 53-62. [CrossRef]

51. Chudov, K.A.; Levchenko, K.S.; Poroshin, N.O.; Shmelin, P.S.; Grebennikov, E.P.; Shchegol'kov, A.V. Synthesis and properties of new Electrochromic derivatives of 3-aryl-4,5-bis(pyridine-4-yl) oxazole. Russ. Chem. Bull. 2019, 68, 1565-1569. [CrossRef]

52. Grimsdale, A.C.; Chan, K.L.; Martin, R.E.; Jokisz, P.G.; Holmes, A.B. Synthesis of Light-Emitting Conjugated Polymers for Applications in Electroluminescent Devices. Chem. Rev. 2009, 109, 897-1091. [CrossRef] [PubMed]

53. Brabec, C.; Dyakanov, V.; Scherf, U. Organic photovoltaics. Energy Environ. Sci. 2009, 2, 251-261. [CrossRef]

54. Sapp, S.; Sotzing, G.A.; Reynolds, J.R. High contrast ratio and fast-switching dual polymer electrochromic devices. Chem. Mater. 1998, 10, 2101-2108. [CrossRef]

55. Jenekhe, S.A.; Kiserow, D.J. Chromogenic effects in polymers: An overview of the driverse ways of tuning optical properties in real time. In 230th ACS National Meeting, Proceedings of the American Chemical Society Symposium Series, Washington, DC, USA, 28 August-1 September 2005; American Chemical Society: Washington, DC, USA, 2005; Volume 888, p. 2. [CrossRef]

56. Beaujuge, P.M.; Ellinger, S.; Reynolds, J.R. Spray processable green to highly transmissive electrochromics via chemically polymerizable donor-acceptor heterocyclic pentamers. Adv. Mater. 2008, 20, 2772-2776. [CrossRef]

57. Dyer, A.L.; Thompson, E.J.; Reynolds, J.R. Completing the Color Palette with Spray-Processable Polymer Electrochromics. ACS Appl. Mater. Interface 2011, 3, 1787-1795. [CrossRef]

58. Thakur, V.K.; Ding, G.; Ma, J.; Lee, P.S.; Lu, X. Hybrid materials and polymer electrolytes for electrochromic device applications. Adv. Mater. 2012, 24, 4071-4096. [CrossRef] [PubMed]

59. Monk, P.M.S.; Mortimer, R.J.; Rosseinsky, D.R. Electrochromism: Fundamentals and Applications; VCH: Weinheim, Germany, 1995; p. 243. [CrossRef]

60. Wen, R.; Niklasson, G.; Granqvist, C. Electrochromic Iridium oxide films: Compatibility with propionic acid, potassium hydroxide, and lithium perchlorate in propylene carbonate. Sol. Energy Mater. Sol. Cells 2013, 120 Pt A, 151-156. [CrossRef]

61. Lin, S.-Y.; Wang, C.-M.; Kao, K.-S.; Chen, Y.-C.; Liu, C.-C. Electrochromic properties of $\mathrm{MoO}_{3}$ thin films derived by a sol-gel process. J. Sol-Gel Sci. Technol. 2010; 53, 51-58. [CrossRef]

62. Korošec, R.C.; Bukovec, P. Sol-Gel Prepared NiO Thin Films for Electrochromic Applications. Acta Chim. Slov. 2006, 53, 136-147.

63. Zelazowska, E.; Rysiakiewicz-Pasek, E. Thin $\mathrm{TiO}_{2}$ films for an electrochromic system. Opt. Mater. 2009, 31, 1802-1804. [CrossRef]

64. Wei, Y.; Zhou, J.; Zheng, J.; Xu, C. Improved stability of electrochromic devices using Ti-doped $\mathrm{V}_{2} \mathrm{O}_{5}$ film. Electrochica Acta 2015, 166, 277-284. [CrossRef]

65. Westphal, T.M.; Cholant, C.M.; Azevedo, C.F.; Moura, E.A.; Silva, D.L.; Lemos, R.M.J.; Pawlicka, A.; Gundel, A.; Flores, W.H.; Avellaneda, C.O. Influence of the $\mathrm{Nb}_{2} \mathrm{O}_{5}$ doping on the electrochemical properties of $\mathrm{V}_{2} \mathrm{O}_{5}$ thin films. J. Electroanal. Chem. 2017, 790, 50-56. [CrossRef]

66. Mansouri, M.; Mahmoodi, T. Ab Initio Investigation on the Effect of Transition Metals Doping and Vacancies in $\mathrm{WO}_{3}$. Acta Phys. Pol. 2016, 129, 8-13. [CrossRef]

67. Ashrit, P. Transition Metal Oxide Thin Film-Based Chromogenics and Devices; Elsevier: Amsterdam, The Netherlands, $2017 ;$ p. 376.

68. Zhang, J.-G.; Benson, D.K.; Tracy, C.E.; Deb, S.K.; Czanderna, A.W.; Bechinger, C. Chromic Mechanism in Amorphous WO 3 Films. In Proceedings of the 190th Electrochemical Society Meeting, San Antonio, TX, USA, 11-13 February 1996; pp. 1-19.

69. Wang, Z.; Chen, G.; Zhang, H.; Liang, L.; Gao, J.; Cao, H. In situ TEM investigation of hexagonal $\mathrm{WO}_{3}$ irreversible transformation to Li 2 WOScr. Material 2021, 203, 114090. [CrossRef]

70. Baloukas, B.; Martinu, $\mathrm{L}$. $\mathrm{WO}_{3} / \mathrm{SiO}_{2}$ composite optical films for the fabrication of electrochromic interference filters. Appl. Opt. 2012, 51, 3346-3356. [CrossRef] [PubMed]

71. Mukherjee, R.; Sahay, P.P. Effect of precursors on the microstructural, optical, electrical and electrochromic properties of $\mathrm{WO}_{3}$ nanocrystalline thin films. J. Mater. Sci. Mater. Electron. 2015, 26, 6293-6305. [CrossRef]

72. Lusis, A.; Kleperis, J.; Pentjuss, E. Model of electrochromic and related phenomena in tungsten oxide thin films. J. Solid State Electrochem. 2003, 7, 106-112. [CrossRef]

73. Khyzhun, O.Y.; Solonin, Y.M. Electronic structure of nanoparticles of substoichometric hexagonal tungsten oxides. In Proceedings of the International Conference on Nanoscience and Technology, Basel, Switzerland, 30 July-4 August 2007; Volume 61, pp. 534-539. [CrossRef]

74. Gabrusenoks, J.V.; Cikmach, P.D.; Lusis, A.R.; Kleperis, J.J.; Ramans, G.M. Electrochromic colour centres in amorphous tungsten trioxide then films. Solid State Ion. 1984, 14, 25-30. [CrossRef]

75. Temmink, A.; Anderson, O.; Bange, K.; Hantsche, H.; Yu, X. Optical absorption of amorphous $\mathrm{WO}_{3}$ and binding state of tungsten. Thin Solid Film. 1990, 192, 211-218. [CrossRef]

76. Niklasson, G.A.; Granqvist, C.G. Electrochromic for smart window: Thin films of tungsten oxide and nickel oxide, and devices based on these. J. Mater. Chem. 2007, 17, 127-156. [CrossRef]

77. Shchegolkov, A.V.; Shchegolkov, A.V. Electrochromic nanostructure $\mathrm{WO}_{3}$ films prepared by electrochemical deposition: Receipt and properties. Perspekt. Mater. 2020, 1, 54-63. [CrossRef] 
78. Pehlivan, I.B. Functionalization of Polymer Electrolytes for Electrochromic Windows; Acta Univ. Upsliensis: Uppsala, Sweden, 2013; p. 174.

79. Rojas-Gonzalez, E.A.; Niklasson, G.A. Coloration of tungsten oxide electrochromic thin films at high bias potentials and low intercalation levels. Mater. Lett. X 2020, 7, 100048. [CrossRef]

80. Vijayakumar, E.; Yun, Y.-H.; Quy, V.H.V.; Lee, Y.-H.; Kang, S.-H.; Ahn, K.-S.; Lee, S.W. Development of tungsten trioxide using pulse and continuous electrodeposition and its properties in electrochromic devices. J. Electrochem. Soc. 2019, 166, 86-92. [CrossRef]

81. Kotok, V.; Kovalenko, V.; Solovov, V.; Zima, O.; Nikolenko, M. Some aspects of the $\mathrm{WO}_{3}$ films electrodeposition for application in electrochromic devices. In Proceedings of the 11th International Students Scientific Conference, "Trans-Mech-Art-Chem" Radom, Poland, 17-20 October 2017.

82. Yoo, S.J.; Lim, J.W.; Sung, Y.-E.; Jung, Y.H.; Choi, H.G.; Kim, D.K. Fast switchable electrochromic properties of tungsten oxide nanowire bundles. Appl. Phys. Lett. 2007, 90, 173126. [CrossRef]

83. Kondalkar, V.V.; Mali, S.S.; Kharade, R.R.; Khot, K.V.; Patil, P.B.; Mane, R.M.; Choudhury, S.; Patilm, P.S.; Hong, C.K.; Kim, J.H.; et al. High perfoming smart electrochromic device based on honeycomb nanostructured $\mathrm{h}-\mathrm{WO}_{3}$ thin films: Hydrothermal assisted synthesis. Dalton Trans. 2015, 44, 2788-2800. [CrossRef] [PubMed]

84. Kwong, W.L.; Savvides, N.; Sorrell, C.C. Electrodeposited nanostructured $\mathrm{WO}_{3}$ thin films for photoelectrochemical applications. Electrochim. Acta 2012, 75, 371-380. [CrossRef]

85. Zhu, T.; Chong, M.N.; Chang, E.S. Nanostructured Tungsten Trioxide Thin Films Synthesized for Photoelectrocatalytic Water Oxidation: A review. ChemSusChem Rev. 2014, 7, 2974-2997. [CrossRef] [PubMed]

86. More, A.J.; Patil, R.S.; Dalavi, D.S.; Mali, S.S.; Hong, C.K.; Gang, M.G.; Kim, J.H.; Patil, P.S. Electrodeposition of nano-granular tungsten oxide thin films for smart window application. Mater. Lett. 2014, 134, 298-301. [CrossRef]

87. Wang, K.; Zhang, H.; Chen, G.; Tian, T.; Tao, K.; Liang, L. Long-term-stable $\mathrm{WO}_{3}$-PB complementary electrochromic devices. J. Alloy. Compd. 2021, 861, 158534. [CrossRef]

88. Zheng, R.; Wang, Y.; Pan, J.; Malik, H.A.; Zhang, H.; Jia, C.; Weng, X.; Xie, J.; Deng, L. Towards Easy-to-assemble, Large Area Smart Windows: All-in-one Cross-Linked Electrochromic Material and Device. ACS Appl. Mater. Interfaces 2020, 12, 27526-27536. [CrossRef]

89. Cai, G.; Wang, J.; Lee, P.S. Next-generation multifunctional electrochromic devices. Acc. Chem. Res. 2016, 49, 1469-1476. [CrossRef]

90. Granqvist, C.G. Transparent conductors as solar energy materials: A panoramic review. Sol. Energy Material. Sol. Cells. 2007, 91, 1529-1598. [CrossRef]

91. Mecerreyes, D.; Marcilla, R.; Ochoteco, E.; Grande, H.; Pomposo, J.A.; Vergaz, R.; Pena, J.M.S. A simplified all-polymer flexible electrochromic device. Electrochim. Acta 2004, 49, 3555-3559. [CrossRef]

92. Gillaspie, D.-T.; Tenent, R.C.; Dillon, A.C. Metal-oxide films for electrochromic applications: Present technology and future directions. J. Mater. Chem. 2010, 20, 9585-9592. [CrossRef]

93. Edwards, P.P.; Porch, A.; Jones, M.O.; Morgan, D.V.; Perks, R.M. Basic materials physics of transparent conducting oxides. Dalton Trans 2004, 19, 2995-3002. [CrossRef]

94. Voronin, A.S.; Ivanchenko, F.S.; Simunin, M.M.; Shiverskiy, A.V.; Aleksandrovsky, A.S.; Nemtsev, I.V.; Fadeev, Y.V.; Karpova, D.V.; Khartov, S.V. High performance hybrid rGO/Ag quasi-periodic mesh transparent electrodes for flexible electrochromic devices Appl. Surf. Sci. 2015, 364, 931-937. [CrossRef]

95. Li, H.; Elezzabi, A.Y. Simultaneously enabling dynamic transparency control and electrical energy storage via electrochromism. Nanoscale Horiz. 2020, 5, 691-695. [CrossRef]

96. Lv, H.; Yang, S.; Li, C.; Han, C.; Tang, Y.; Li, X.; Wang, W.; Li, H.; Zhi, C. Suppressing passivation layer of Al anode aqueous electrolytes by complexation of $\mathrm{H}_{2} \mathrm{PO}_{4}{ }^{-}$to $\mathrm{Al}^{3+}$ and an electrochromic $\mathrm{Al}$ ion battery. Energy Stor. Mater. 2021, 39, $412-418$. [CrossRef]

97. Barbosa, P.C.; Silva, M.M.; Smith, M.J.; Goncalves, A.; Fortunato, E. Studies of solid-state electrochromic devices based on $\mathrm{PEO} /$ siliceous hybrids doped with lithium perchlorate. Electrochim. Acta. 2007, 52, 2938-2943. [CrossRef]

98. Park, S.-I.; Quan, Y.-J.; Kim, S.-H.; Kim, H.; Kim, S.; Chun, D.-M.; Lee, C.S.; Taya, M.; Chu, W.-S.; Ahn, S.-H. A Review on Fabrication Processes for Electrochromic Devices. Int. J. Precis. Eng. Manuf.-Green Technol. 2016; 3, 397-421. [CrossRef]

99. Jain, N.K.; Sawant, M.S.; Nikam, S.H.; Jhavar, S. Metal deposition: Plasma-based processes. In Encyclopedia of Plasma Technology, 1st ed.; Taylor and Francis: New York, NY, USA, 2016; pp. 722-740. [CrossRef]

100. Subrahmanyam, A.; Karuppasamy, A. Optical and electrochromic properties of oxygen sputtered tungsten oxide $\left(\mathrm{WO}_{3}\right)$ thin films. Sol. Energy Mater. Sol. Cells 2007, 91, 266-274. [CrossRef]

101. Hepel, M.; Redmond, H. Large cation model of dissociative reduction of electrochromic $\mathrm{WO}_{3-\mathrm{x}}$ films. Cent. Eur. J. Chem. 2009, 7 , 234-245. [CrossRef]

102. Zhou, K.; Wang, H.; Liu, J. Coloration and Ion Insertion Kinetics Study in Electrochromic $\mathrm{WO}_{3}$ Films by Chronoamperometry. Int. J. Electrochem. Sci. 2020, 15, 7821-7832. [CrossRef]

103. Kwong, W.K.; Qiu, H.; Nakaruk, A.; Koshy, P.; Sorrel, C.C. Photoelectrochemical Properties of $\mathrm{WO}_{3}$ Thin Films Prepared by Electrodeposition. Energy Procedia 2013, 34, 617. [CrossRef]

104. Velevska, J.; Stojanov, N.; Pecovska-Gjorgevich, M.; Najdoski, M. Electrochromism in tungsten oxide thin films prepared by chemical bath deposition. J. Electrochem. Sci. Eng. 2017, 7, 27. [CrossRef] 
105. Pauporte, T. A simplified Method for $\mathrm{WO}_{3}$ Electrodeposition. J. Electrochem. Soc. 2002, 149, 539-545. [CrossRef]

106. Arakaki, J.; Reyes, R.; Horn, M.; Estrada, W. Electrochromism in $\mathrm{NiO}_{\mathrm{x}}$ and $\mathrm{WO}_{\mathrm{x}}$ obtained by spray pyrolysis. Sol. Energy Mater. Sol. Cells 1995, 37, 33-41. [CrossRef]

107. Deepa, M.; Srivastava, A.K.; Kar, M.; Agnihotry, S.A. A case study of optical properties and structure of sol-gel derived nanocrystalline electrochromic $\mathrm{WO}_{3}$ films. J. Phys. D Appl. Phys. 2006, 39, 1885-1893. [CrossRef]

108. Solarska, R.; Alexander, B.D.; Augustynski, J. Electrochromic and structural characteristics of mesoporous $\mathrm{WO}_{3}$ films prepared by a sol-gel method. J. Solid State Electrochem. 2004, 8, 748-756. [CrossRef]

109. Valyukh, I.; Green, S.; Arwin, H.; Niklasson, G.A.; Wackelgard, E.; Granqvist, C.G. Spectroscopic ellipsometry characterization of electrochromic tungsten oxide and nickel oxide thin films made by sputter deposition. Sol. Energy Mater. Sol. Cells 2010, 94, 724-732. [CrossRef]

110. Yamada, Y.; Tabata, K.; Yashima, T. The character of $\mathrm{WO}_{3}$ film prepared with RF sputtering. Sol. Energy Mater. Sol. Cells 2007, 91, 29-37. [CrossRef]

111. Atak, G.; Pehlivan, I.B.; Montero, J.; Granqvist, C.G.; Niklasson, G.A. Electrochromic tungsten oxide films prepared by sputtering: Optimizing cycling durability by judicious choice of deposition parameters. Electrochim. Acta 2021, 367, 137233. [CrossRef]

112. Qiu, D.; Ji, H.; Zhang, X.; Zhang, H.; Cao, H.; Chen, G.; Tian, T.; Chen, C.; Guo, X.; Liang, L.; et al. Electrochromism of nanocrystal-in-glass tungsten oxide thin films under various conduction cations. Inorg. Chem. 2019, 58, 2089-2098. [CrossRef]

113. Evecan, D.; Zayim, E. Highly uniform electrochromic tungsten oxide thin films deposite be e-beam evaporation for energy saving systems. Curr. Appl. Phys. 2019, 19, 198-203. [CrossRef]

114. Vernardou, D.; Psifis, K.; Louloudakis, D.; Papadimitropoulos, G.; Davazoglou, D.; Katsarakis, N.; Koudoumas, E. Low Pressure $\mathrm{CVD}$ of Electrochromic $\mathrm{WO}_{3}$ at $400{ }^{\circ} \mathrm{C}$. J. Electrochem. Soc. 2015, 162, 579-582. [CrossRef]

115. Kraft, A.; Rottman, M. Properties, performance and current status of the laminated electrochromic glass of gesimat. Sol. Energy Mater. Sol. Cells 2009, 93, 2088-2092. [CrossRef]

116. Brinker, C.; Scherer, G. Sol-Gel Science: The Physics and Chemistry of Sol-Gel Processing; Academic Press, Inc.: Cambridge, MA, USA, 1990; p. 908.

117. Lenormand, P.; Rieu, M.; Julbe, M.; Castilio, A.; Ansart, S.; Ansart, F. Potentialities of the sol-gel route to develop cathode and electrolyte thick: Application to SOFC systems. Surf. Coat. Technol. 2008, 203, 901-904. [CrossRef]

118. Agrawal, A.; Cronin, J.P.; Zhang, R. Review of solid-state electrochromic coatings produced using sol-gel techniques. Sol. Energy Mater. Sol. Cells 1993, 31, 9-21. [CrossRef]

119. Cronin, J.P.; Tarico, D.J.; Tonazzi, J.C.L.; Agrawal, A.; Kennedy, S.R. Microstructure and properties of sol-gel deposited WO 3 coatings for large-area electrochromic windows. Sol. Energy Mater. Sol. Cells 1993, 28, 371-386. [CrossRef]

120. Mujawar, S.; Inamdar, A.; Korosec, C.; Patil, R.C.; Patil, P. Electrochromism in Composite $\mathrm{WO}_{3}-\mathrm{Nb}_{2} \mathrm{O}_{5}$ Thin Films Synthesized by Spray Pyrolysis Technique. J. Appl. Electrochem. 2011, 41, 397-421. [CrossRef]

121. Bertus, L.; Enesca, A.; Duta, A. Influence of spray pyrolysis deposition parameters on the optoelectronic properties of $\mathrm{WO}_{3}$ thin films. Thin Solid Film. 2012, 520, 4282-4290. [CrossRef]

122. Patil, C.; Tarwal, N.; Jadhav, P.; Shinde, P.; Deshmukh, H. Electrochromic Performance of the $\mathrm{Mixed}_{2} \mathrm{~V}_{5}-\mathrm{WO}_{3}$ Thin Films Synthezed by Pulsed Spray Pyrolysis Technique. Curr. Appl. Phys. 2014, 14, 389-395. [CrossRef]

123. Bathe, S.R.; Patil, P.S. Electrochromic characteristics of pulsed spray pyrolyzed polycrystalline $\mathrm{WO}_{3}$ thin films. Smart Mater. Struct. 2009, 18, 1-7. [CrossRef]

124. Kelly, P.; Bradley, J. Pulsed magnetron sputtering-process overview and applications. J. Optoelectron. Adv. Mater. 2009, 11, 1101-1107.

125. Chen, H.-C.; Jan, D.-J.; Chen, C.-H. Investigation of optical and electrochromic properties of tungsten oxide deposited with horizontal DC and DC pulse magnetron sputtering. Jpn. J. Appl. Phys. 2012, 51, 45503. [CrossRef]

126. Chen, H.-C.; Chen, D.-J.; Huang, K.-T. Bond and Electrochromic Properties of $\mathrm{WO}_{3}$ Films Deposited with Horizontal DC, Pulsed DC, and RF Sputtering. Electrochim. Acta 2013, 93, 307-313. [CrossRef]

127. Zhi, M.; Shi, Q.; Wang, M.; Wang, Q. Sol-gel fabrication $\mathrm{WO}_{3} / \mathrm{rGO}$ nanocomposite film with enhanced electrochromic performance. RSC Adv. 2016, 6, 67488-67494. [CrossRef]

128. Wang, J.M.; Khoo, E.; Lee, P.S.; Ma, J. Controlled synthesis of $\mathrm{WO}_{3}$ nanorod and their electrochromic properties in $\mathrm{H}_{2} \mathrm{SO}_{4}$ electrolyte. J. Phys. Chem. C 2009, 113, 9655-9658. [CrossRef]

129. Lee, S.-H.; Deshpande, R.; Parilla, P.A.; Jones, K.M.; To, B.; Mahan, A.H.; Dillon, A.C. Crystalline $\mathrm{WO}_{3}$ nanoparticles for highly improved electrochromic applications. Adv. Mater. 2006, 18, 763-766. [CrossRef]

130. Dinh, N.N.; Hinh, D.H.; Thao, T.T.; Vo-Van, T. Mixed Nanostructured Ti-W Oxides Filsms for Efficient Electrochromic Windows. J. Nanomater. 2012, 2012, 1-7. [CrossRef]

131. Niu, J.; Wang, Y.; Zou, X.; Tan, Y.; Jia, C.; Weng, X.; Deng, L. Infrared electrochromic materials, devices and applications. Appl. Mater. Today, 2021; 24, 1-27. [CrossRef]

132. Costa, C.; Pinheiro, C.; Henriques, I.; Laia, C.A.T. Inkjet Printing of Sol-Gel Synthesized Hydrated Tungsten Oxide Nanoparticles for Flexible Electrochromic Devices. Appl. Mater. Interfaces 2012, 4, 1330-1340. [CrossRef] [PubMed]

133. Luo, J.; Zeng, Q.; Long, Y.; Wang, Y. Preparation of Nano-Polycrystalline $\mathrm{WO}_{3}$ Thin Films and Their Solid-State Electrochromic Display Devices. J. Nanosci. Nanotechnol. 2013, 13, 1372-1376. [CrossRef] 
134. Llordés, A.; Garcia, G.; Gazquez, J.; Milliron, D.J. Tunnable near-infrared and visible-light transmittance in nanocrystal-in-glass composites. Nature 2013, 500, 323-326. [CrossRef]

135. Shchegolkov, A.V.; Knyazeva, L.G.; Shchegolkov, A.V.; Komarov, F.F.; Parfimovich, I.D. The study of electrochromic films $\mathrm{WO}_{3}(\mathrm{GO})$ obtained by electrochemical deposition: Optical and electromagnetic properties. Mendeleev J. Russ. Chem. Soc. 2020, LXIV, 55-62.

136. Zhao, Q.; Yasi, F.; Qiao, K.; Wei, W.; Yao, Y.; Gao, Y. Printing of $\mathrm{WO}_{3} / \mathrm{ITO}$ nanocomposite electrochromic smart windows. Sol. Energy Mater Sol. Cells 2019, 194, 95-102. [CrossRef]

137. Yao, Y.; Zhao, Q.; Wei, W.; Chen, Z.; Zhu, Y.; Zhang, P.; Zhang, Z.; Gao, Y. WO 3 quantum-dots electrochromism. Nano Energy 2020, $68,104350$. [CrossRef]

138. Xiong, S.; Yin, S.; Wang, Y.; Kong, Z.; Lan, J.; Zhang, R.; Gong, M.; Wu, B.; Chu, J.; Wang, X. Organic/inorganic electrochromic nanocomposites with various interfacial interactions: A review. Mater. Sci. Eng. B 2017, 221, 41-53. [CrossRef] 